\title{
部材破断を考慮したブレース付鋼構造骨組の振動台実験 \\ SHAKE TABLE TESTING OF STEEL BRACED FRAME CONSIDERING MEMBER FRACTURE
}

\author{
松井良太*1, 寺澤友貴*2，竹内 徹*3 \\ Ryota MATSUI, Yuki TERAZAWA and Toru TAKEUCHI
}

\begin{abstract}
The authors have proposed a method to assess local fracture of concentric braced frames under cyclic loading from global member results termed the Direct Local Strain Evaluation M ethod. In this method there is no need to use detailed member shell models to estimate the strain at the fracture point in the braces. This enables accurate time history response analysis using less computationally intensive stick models, while including the effect of local member fracture. However, up to now, the accuracy of the proposed method has only been validated under static loading. This research validates the proposed method with dynamic numeric and shake table testing. The proposed method is effective in simulating the braced frame response including the brace fracture under dynamic loading.
\end{abstract}

Keywords: M ember F racture, Steel F rame, Seismic Performance, Shake Table Testing 部材破断，鋼構造骨組，而震性能，振動台実験

\section{1. 序}

今後高い確率で極大の海溝型地震である東海, 東南海, 南海地震 に代表されるような長周期かつ大規模な地震動が発生すると予測さ

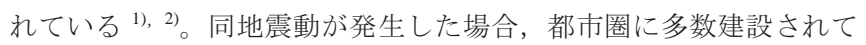
いる中高層ブレース付鋼構造骨組において部材破断が生じる可能性 があることが指摘されており ${ }^{31}$ ， 4)，これらの施設では部材破断を考 慮した安全性検討が急務となっている。

筆者らはこれまで，ブレース部材や梁端部が繰返し荷重を受け， 塑性歪が集中し破断する挙動を, 部材局部の力学モデルから導かれ る数式および全体の変形から評価する簡易な手法を提案してき た ${ }^{5)-9)}$ 。同手法は従来の汎用的な時刻歴応答解析プログラムに容易 に組み込むことができ，ブレース付鋼構造骨組がブレース部材や梁 端部が破断した後, どのような動的性状を示すか比較検証すること ができる。文献 8)では, 同手法を用いて極大地震動を受ける 7 層の ブレース付鋼構造骨組の時刻歴応答解析し, 図 1 に示すようにブレ 一ス部材や梁端部における破断を考慮した場合, 非考慮の場合に比 して, 変位応答が 2 3 倍程度増加し, またブレース部材や梁端部の 破断に伴い層の柱梁に入力される累積吸収エネルギー量は $1.5 \sim 2.0$ 倍程度まで増加し, 各層の梁端部が連鎖的に破断する危険性がある ことを指摘している。また， 7 層，15 層，21 層のラーメン骨組を対 象として, ブレースおよび梁端部の部材破断の非考慮／考慮が地震 応答特性に与える影響について同手法を用いて分析し, 骨組の最大 層間変形角が $1 / 50 \mathrm{rad}$ を上回る場合には，その影響が顕著であるこ
とを確認している9 。これらの結果は, 極大地震動を受けるブレー 又付鋼構造骨組の動的挙動を適切に捉えるためには，部材破断を考 慮する必要があることを示唆している。

しかし, 上記の部材破断評価手法の妥当性や精度は静的な部材実 験結果との比較のみでしか確認されておらず $\left.{ }^{31}, 19\right)$, 動的入力や骨組 内のブレースに対する精度は不明な点があり, 部材破断を考慮した 時刻歴応答解析と実際のブレース付鋼構造骨組の崩壊挙動との対応 は未確認である。そこで，本研究は実大の $1 / 5$ サイズで 1 スパンの ブレース付鋼構造骨組を対象に慣性質量装置を用いた実験システム 用いて各種載荷実験を実施し，ブレースの動的崩壊挙動や梁端部に 亀裂が生じて骨組が倒壊に至るまでの地震応答性状を分析し, 動的 入力下における提案手法の評価精度を検証する。次に有限要素法解 析を用いて局部の歪分布性状を分析する。さらに，同手法を組み込 んだ時刻歷応答解析を用いて, ブレース亀裂発生時期やブレース破 断後の骨組の地震応答性状と振動台実験結果との対応を検証する。

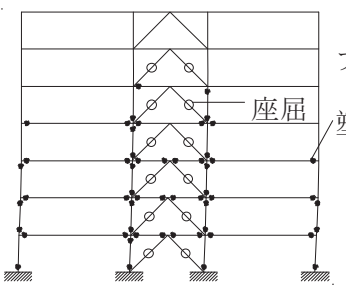

(a) 破断非考慮

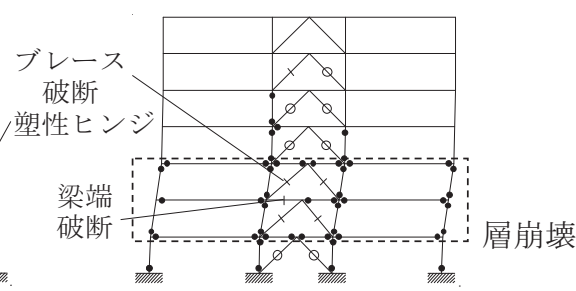

(b) ブレース部材，梁端破断考虑
図 17 層のブレース付骨組の変位図，機構図，座屈
*1 東京丁業大学 建築学系 助教 · 博十 (丁学)

*2 東京工業大学 建築学系 大学院生·修士 (工学) (日本学術振興会特別研究員 DC1)

*3 東京工業大学 建築学系 教授·博士 (工学)
Assist. Prof., Dept. of Arch, and Build. Eng., Tokyo Institute of Technology, Dr.Eng. Grad. Stud., Dept. of Arch. and Build. Eng., Tokyo Institute of Technology, M.Eng. (Research Fellow of the Japan Society for the Promotion of Science)

Prof., Dept. of Arch. and Build. Eng., Tokyo Institute of Technology, Dr.Eng. 


\section{2. ブレース付鋼構造骨組の実験概要}

部材破断を伴うブレース付鋼構造骨組の動的崩壊挙動を検証する。 初めに試験体の基本的力学特性を把握するための準静的繰返し載荷 試験を行い, 図 2 に示寸力学モデルの妥当性や各種ブレース付架構 の累積変形性能を確認し, 次に振動台実験を実施する。

\section{1 想定建物と試験体概要}

図 2 に想定建物と試験体概要を示す。想定建物は建物高さ $25 \mathrm{~m}$ 程 度の中低層鉄骨造建築物を対象とし, 柱脚部はピン治具で接合され, ブレースが偏心配置された第 1 層を検討範囲としてモデル化する。 試験体はスパン $6.8 \mathrm{~m}$, 柱高さ $3.6 \mathrm{~m}$ の門型柱梁骨組に各種ブレース を配置した鋼構造架構の $1 / 5$ 縮小模型とする。

図 3 に試験体図を示す。梁断面形状は H-130×40×2.3×2.3, 梁材長 は $1360 \mathrm{~mm}$ ，柱断面形状は $\square-100 \times 100 \times 3.2$ ，ピン支承を考慮した柱 材長は $720 \mathrm{~mm}$, 接合部は板厚 $9 \mathrm{~mm}$ の通しダイアフラム形式とする。 ブレースは断面積が等しい断面形状 $\phi 50.8 \times 1$.2(径厚比 $D / t=42.3$ )の円 形鋼管，断面形状 $\phi 27.2 \times 2.3$ (径厚比 $\mathrm{D} / \mathrm{t}=11.8$ ) の円形鋼管，断面形状 PL-6×30 の平鋼の 3 種類を採用し, 本論ではそれぞれ薄肉鋼管ブレ 一ス, 厚肉鋼管ブレース, 平鋼ブレースと呼び, 試験体名として採 用する。鋼管ブレース接合部は板厚 $6 \mathrm{~mm}$ の G.PL をブレース切久き 部に捙し込み回し溶接合とし, 平鋼ブレース接合部はボルトと接合 する。表 1 に機械的性質を含めた試験体諸元を示す。柱は梁と比べ て 2 倍程度の耐力を有しており，本実験載荷プログラムの範囲では 応力が弾性範囲に留まる設計となっている。薄肉鋼管ブレース試験 体は準静的繰返し載荷試験と振動台実験で異なる鋼材ロールを使用 しているものの, 各部材耐力は概初同等である。鋼管ブレースは剛 接合として $0.5 L_{b}$ (図 3 参照), 平鋼ブレースはピン接合として $L_{b}$ を座 屈長とし, 座屈応力度 $\sigma_{\mathrm{cr}}$ 鋼構造設計規準に従い評価する。

\section{2 慣性質量装置を用いた実験システム}

振動台実験は構造物の動的応答について, 総合的知見を与える有 力な手法であるものの, 理想的な実大立体架構の振動台実験は大型 の試験体や振動台が必要となる。一方, 慣性質量装置とは, 部分架 構に対し適切な慣性力を与え, 実際の応答の一部を簡易に再現寸る ための機構であり, 既往の研究では図 4 に示寸ような装置構成が提 案されている例えば 10)-13)。これらは重錘の設置方法により (1)比較的小 規模に納まるが転倒防止架構を要する「試験体一体型」, (2)支持架構 は不要だが振り子復元力の考慮を要する「懸垂型」, (3)複層化できる が支持架構の支承部摩擦抵抗の考慮を要する「自立型」の 3 種類に 分類される ${ }^{12)}$ 。本研究では試験フレームに組み込まれた $1.2 \mathrm{~m} \times 1.7 \mathrm{~m}$ の小型振動台への適用を考慮し, 同図(d)に示寸「試験体一体型」と 「自立型」を組み合わせ, 大変形時のP 4 効果による倒壊挙動を模擬 できる慣性質量装置を採用して実験システムを構築する。

図 5 に実験セットアップ図を示す。実験システムは試験フレーム および振動台上に設置された下部治具, ロッキングカラム, 加力治 具, 反力治具および重錘で構成され, 下部治具は PC 鋼棒を用いて 振動台に緊結する。試験体は下部治具にピン接合し, 加力治具を介 して実験装置と接続する。重錘を支持するロッキングカラムは両端 ピン接合とし, 重鍾の自重は支持するが，慣性力と大変形時のP $\Delta$ 効果による付加モーメントのみを試験体に与える ${ }^{13)}$ 。ピン部は円筒 ころ軸受を内蔵して振動時の摩擦抵抗を軽減する。ロッキングカラ ムの限界層間変形角は約 1/2 rad である。本実験システムは重錘の積

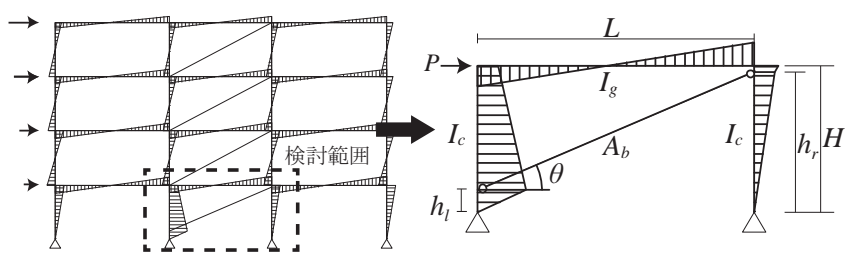

図 2 想定建物と検討範囲のモデル化

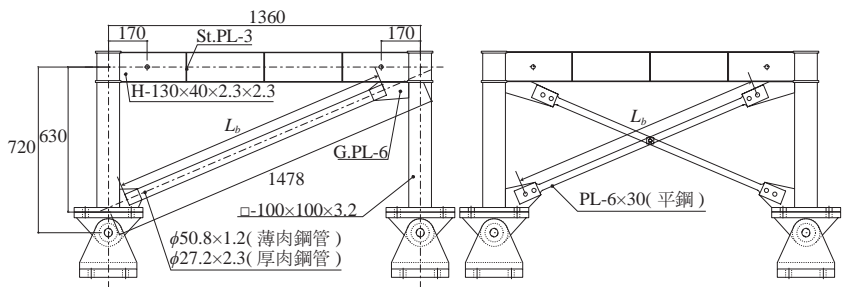

(a) 薄肉鋼管ブレース試験体 $\quad$ (b) 平鋼ブレース試験体

図 3 試験体図(ピン支承は共用)

表 1 試験体諸元

(a) 柱梁骨組部(全試験体共通)

\begin{tabular}{|c|c|c|c|c|c|c|}
\hline & & $\begin{array}{c}\text { 断面形状 } \\
\text { (材種) }\end{array}$ & $\begin{array}{l}\text { 降伏応力度 } \\
\sigma_{y}\left(\mathrm{~N} / \mathrm{mm}^{2}\right)\end{array}$ & $\begin{array}{c}\text { 引張強さ } \\
\sigma_{\mathrm{u}}\left(\mathrm{N} / \mathrm{mm}^{2}\right) \\
\end{array}$ & $\begin{array}{c}\text { 降伏 } \\
M_{y}(k N m\end{array}$ & $\begin{array}{c}\text { 全塑性 } \\
M_{p}(k N m)\end{array}$ \\
\hline 柱 & $\begin{array}{c}\text { 準静的繰返し } \\
\text { 載荷実験 }\end{array}$ & \multirow{2}{*}{$\begin{array}{c}\square-100 \times 100 \times 3.2 \\
\text { (STKR } 400)\end{array}$} & 310 & 435 & 12.0 & 14.0 \\
\hline & 振動台実験 & & 337 & 436 & 12.6 & 14.7 \\
\hline \multirow[t]{2}{*}{ 梁 } & $\begin{array}{c}\text { 準静的繰返し } \\
\text { 載荷実験 }\end{array}$ & \multirow{2}{*}{$\begin{array}{c}\mathrm{H}-130 \times 40 \times 2.3 \times 2.3 \\
(\mathrm{SS} 400)\end{array}$} & 354 & 444 & 6.16 & 7.43 \\
\hline & 振動台実験 & & 340 & 437 & 5.91 & 7.14 \\
\hline
\end{tabular}

\begin{tabular}{|c|c|c|c|c|c|c|}
\hline \multicolumn{2}{|c|}{$\begin{array}{c}\text { ブレース名称 } \\
\text { ※試験体名として採用 } \\
\end{array}$} & $\begin{array}{c}\begin{array}{c}\text { 断面形状 } \\
\text { (材種) }\end{array} \\
\end{array}$ & \begin{tabular}{|c|} 
径厚比 \\
$\mathrm{D} / \mathrm{t}$ \\
\end{tabular} & $\begin{array}{l}\text { 断面積 } \\
\mathrm{A}\left(\mathrm{mm}^{2}\right) \\
\end{array}$ & \multirow{2}{*}{$\begin{array}{c}\begin{array}{c}\text { 降伏応力度 } \\
\sigma_{y}\left(\mathrm{~N} / \mathrm{mm}^{2}\right)\end{array} \\
270\end{array}$} & \multirow{2}{*}{\begin{tabular}{|l}
$\begin{array}{l}\text { 座屈応力度 } \\
\sigma_{\mathrm{cr}}\left(\mathrm{N} / \mathrm{mm}^{2}\right)\end{array}$ \\
259 (剛接合)
\end{tabular}} \\
\hline 薄肉鋼管 & $\begin{array}{c}\text { 準静的繰返し } \\
\text { 載荷実験 }\end{array}$ & $\phi 50.8 \times 1.2$ & 42.3 & \multirow{4}{*}{ 約180 } & & \\
\hline & 振動台実験 & & & & 266 & 256(剛接合) \\
\hline $\begin{array}{l}\text { 厚肉鋼管 } \\
\text { ブレース }\end{array}$ & \multirow{2}{*}{$\begin{array}{c}\text { 準静的繰返L } \\
\text { 載荷実験 }\end{array}$} & $\begin{array}{l}\phi 27.2 \times 2.3 \\
(S T K 400)\end{array}$ & 11.8 & & 401 & 307(剛接合) \\
\hline $\begin{array}{c}\text { 平鋼 } \\
\text { ブレース }\end{array}$ & & $\begin{array}{l}P L-6 \times 30 \\
(S S 400)\end{array}$ & - & & 301 & 5(ピン接合) \\
\hline
\end{tabular}

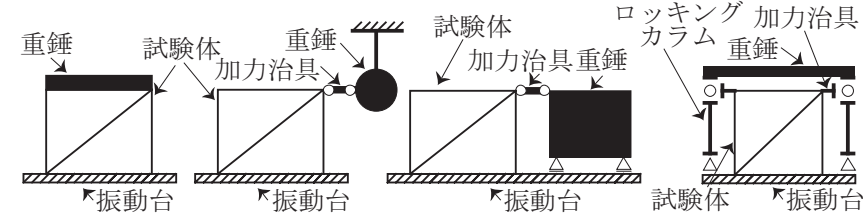
カラム

(a) 試験体一体型 ${ }^{11), 13)}$ (b) 懸垂型 ${ }^{12}$

(c) 自立型 ${ }^{10)}$

(d) 本装置構成 $((a)+(c))$

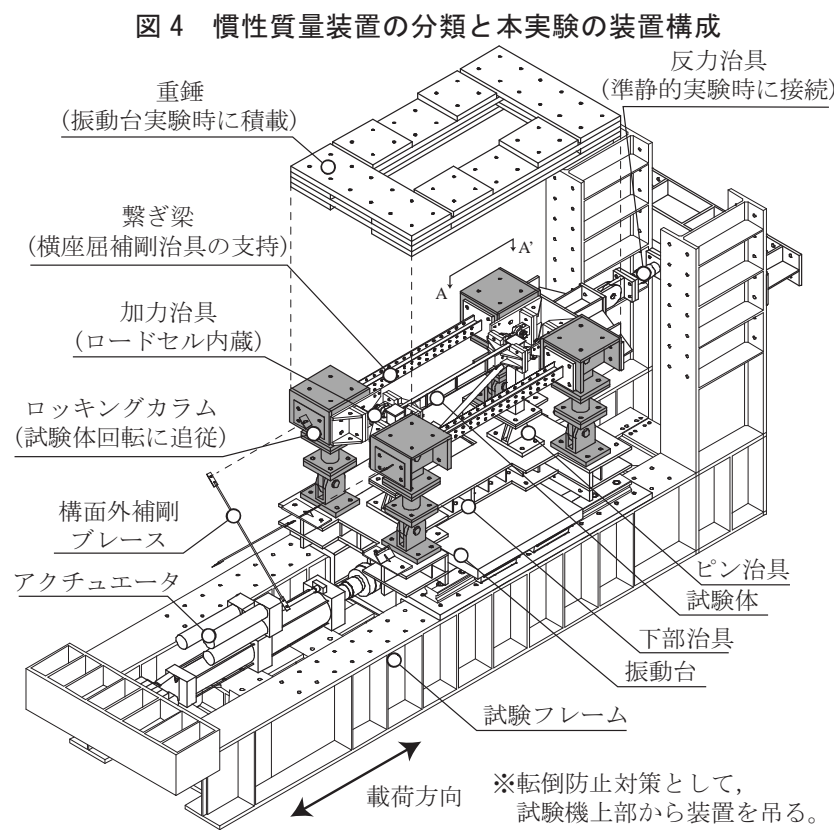

図 5 慣性質量装置を用いた実験システムとセットアップ 
載により振動台実験用の慣性質量装置を構成する他, 反力治具の接 続により静的載荷実験も行える設計となっている。本実験の重錘と 装置柱頭ピンブロックを考虑した慣性質量は $3.6 \times 10^{3} \mathrm{~kg}$ である。

図 6 に各部詳細図を示寸。図 6(a)に示すように, 加力治具は層せ ん断力を計測するためのダンベル型ロードセルを有し, 試験体とロ ッキングカラムをピン接合する。ダンベル型ロードセルは高耐力を 有する SCM 材 $\left(\sigma_{\mathrm{y}}=700 \mathrm{~N} / \mathrm{mm}^{2}\right.$ 以上)を用いて製作し, ピンは球面すべ り軸受けにより面外曲げを解放する。ダンベル型ロードセルは, 反 力治具に内蔵される市販ロードセルとの比較から, 荷重 $60 \mathrm{kN}$ 程度 に対し誤差 $2 \mathrm{kN}$ 程度の精度で荷重を計測できることを確認している。 また, 図 6(b)に示すように, 繋ぎ梁(図 5 参照)との間に横座屈補剛 材を設置し, 図 6(c)に示すように, 加力治具から試験体柱頭部の骨 組面外方向の振動を拘束する治具を設ける。

\section{3 計測計画と数值算出}

図 7 に計測項目を示す。変位は振動台外部に設置したレーザー変 位計より計測し層間変形角の算出に用いる。加速度は下部治具上部, 試験体梁上フランジ，重錘上部に設置した加速度計より計測する。 慣性力は応答加速度と慣性質量より算出する。層せん断力は準静的 繰返し載荷試験では反力治具内のロードセルより計測し, 振動台実 験では図 6(a)に示すダンベル型ロードセルより計測する。柱梁骨組 負担せん断力は図 7 に示寸ように, 柱表面に貼付した歪ゲージ 2 点 間の曲げ歪勾配より算出する。ブレース負担せん断力は層せん断力 と柱梁骨組負担せん断力の差分として算出する。本実験では, 変位 および荷重はブレース引張方向を正と定義し, 図 3 に示すブレース 芯々間距離と軸変形量よりブレース等価軸歪 $\varepsilon_{\mathrm{n}}$ を算出し, 公称断面 積よりブレース等価軸応力度 $\sigma_{\mathrm{n}}$ を算出する。また, 振動台実験はサ ンプリング周波数 $1 \mathrm{kHz}$ ，ローパスフィルタ $200 \mathrm{~Hz}$ で計測する。

図 8 に線材による力学モデルを用いた試験体曲げモーメント分布 の簡易評価を示す。本試験体はブレースが柱梁芯に対して偏心配置 されており, 曲げモーメント分布はブレース軸力による曲げ戻しを 受け，同図(a)と(b)を重㸚わせた同図(c)および(d)で評価される。 本実験では，同図曲げモーメント分布と歪ゲージより算出した柱の 作用曲げモーメントより, 梁端曲げモーメントは下式で評価する。

$$
\begin{aligned}
& M_{L}=E Z_{c} \varepsilon_{b \mid 1}+Q_{C L} L_{1} \\
& M_{R}=E Z_{c} \varepsilon_{b r 1}+Q_{C R} L_{1}+Q_{b}\left(H-h_{r}\right)
\end{aligned}
$$

ここに, E はヤング率, $\mathrm{Z}_{\mathrm{c}}$ は柱断面係数, $\varepsilon_{\mathrm{b}}$ は柱表面曲げ歪, $\mathrm{L}_{1}=240 \mathrm{~mm}$ (図 7 参照)である。水平力分担率は $Q_{b}:\left(Q_{C L}+Q_{C R}\right)=1.07:-0.07$ であ り, 弾性範囲でブレース部は層せん断力を支配的に負担する。また, ブレース塑性化後は同図(a)の曲げモーメント分布の割合が増加す るため，梁端曲げモーメントは部材降伏後も逆対称となる。

\section{4 載荷プログラム}

準静的繰返し載荷実験は, 反力治具を接続した実験システムにア クチュエータから強制水平変位を与え変位制御で試験体に載荷する。 図 9 に載荷履歴を示す。実験は層間変形角 $\varphi= \pm 1 / 500, \pm 1 / 250$, $\pm 1 / 100 ， \pm 1 / 50 ， \pm 1 / 33 \mathrm{rad}$ の正負交番漸増繰返しの履歴を採用し, その後は梁に亀裂発生するまで， $\varphi= \pm 1 / 33 \mathrm{rad}$ で繰返し載荷する。 振動台実験は弾性振動実験と倒壊実験を行う。表 2 に載荷メニュ 一を示す。弾性振動実験では系の固有振動特性を把握する。倒壊実

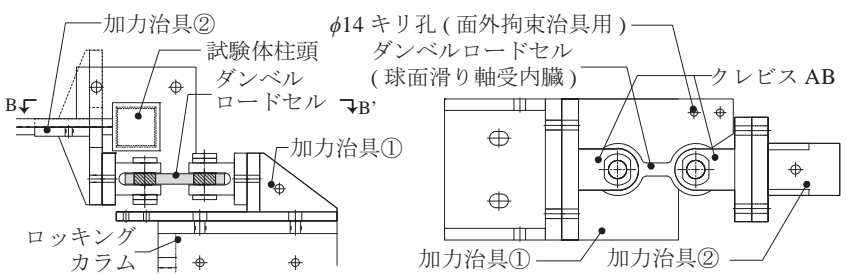

(1) $A-A^{\prime}$ 矢視図

(a) 加力治具

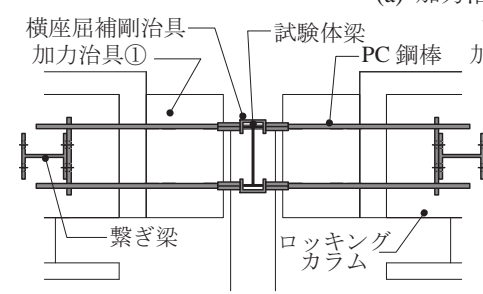

(b) 横座屈補剛治具(全 3 个所, 図 7 参照)

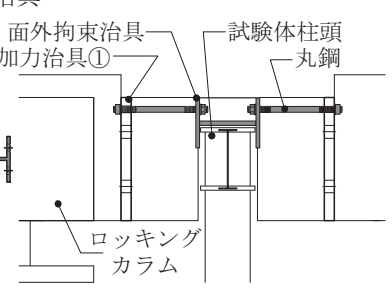

(c) 面外拘束治具

\section{図 6 各部詳細図}

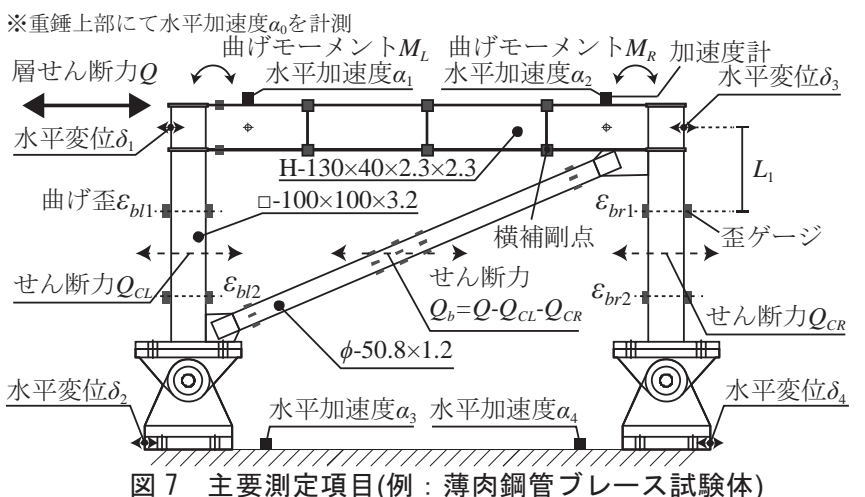

図 7 主要測定項目(例：薄肉鋼管ブレース試験体)

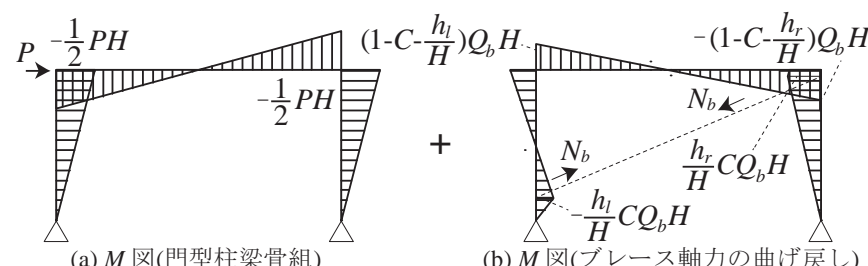

(a) M 図(門型柱梁骨組)

(b) M 図(ブレース軸力の曲げ扊し)

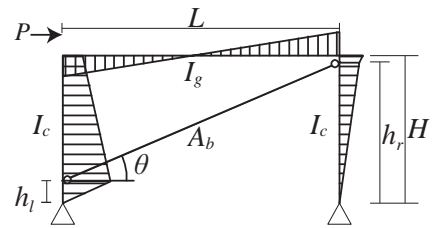

(c) 試験体 M 図((a)+(b))

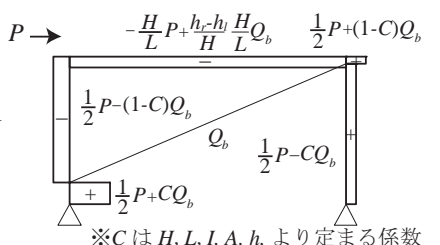

(d) 試験体 Q 図((a)+(b))

図 8 線材モデルを用いた曲げモーメント分布簡易評価

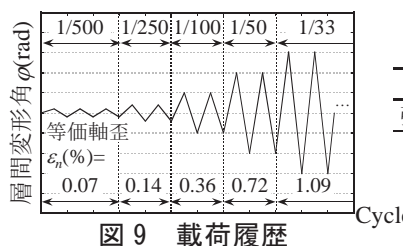

(準静的繰返し載荷実験)

\section{表 2 載荷メニュー(振動台実験)}

\begin{tabular}{c|c}
\hline 試験名称 & 入力波形 \\
\hline 弾性振動実験 & 正弦波スウィープ加振 \\
\hline \multirow{3}{*}{ 倒壊実験 } & EI Centro観測波 倍率 $100 \%$ \\
\cline { 2 - 2 } & (PGA $=8.0 \mathrm{~m} / \mathrm{s}^{2}, \quad$ 2回) \\
\cline { 2 - 2 } & El Centro観測波 倍率150\% \\
& (PGA $=11.9 \mathrm{~m} / \mathrm{s}^{2}$, 倒壊まで) \\
\hline
\end{tabular}

験は梁が亀裂発生するまで地震動を繰返し入力し，部材破断を伴う 地震応答を検証する。入力地震動は相似側を考慮して時間軸を 1/ $\sqrt{5}$ 倍した El CentroNS 観測波を採用し, 実大換算で最大速 度 50kine に規準化した地震動を倍率 100\% と定義する。倒壊実験は 倍率 $100 \%$ 入力を 2 回繰り返した後, 倍率 150\%入力を倒壊するまで 繰返す。ここで, 試験体の倒壊はFEMA-35014)で定められた 4 12 層 建物の層間変形角許容值 $\varphi= \pm 1 / 12.5 \mathrm{rad}$ を超えた状態と定義する。 


\section{3. ブレース付鋼構造骨組の実験結果}

\section{1 準静的繰返し載荷実験}

本節では断面積が概ね等しく断面が異なる薄肉鋼管ブレース試験 体 $(D / t=42.3)$ ，厚肉鋼管ブレース試験体 $(D / t=11.8)$, 平鋼ブレース試 験体を対象として準静的繰返し載荷実験を実施した結果を述へ，断 面形状が累積変形性能に与える影響を分析する。図 10 図 12 に実験 結果を, 写真 1 に試験体状況を示す。平鋼ブレースの負担せん断力 および等価軸応力度は 2 本の合計值として示す。

薄肉鋼管ブレース試験体は, 図 10(a)に示寸ように, $\varphi=1 / 100 \mathrm{rad}$ で骨組面外方向にブレースが全体座屈を生じ， $\varphi=1 / 50 \mathrm{rad}$ の 1cycle でブレース中央部に局部座屈が発生し(写真 1(a)), 2cycle で柱脚側端

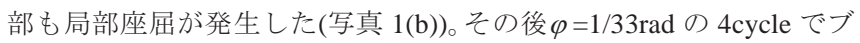
レース中央部に亀裂発生, 7cycle で端部に亀裂発生したものの, 載 荷終了時まで全断面破断に至らず, 図 10(a)に示すようにブレースは 荷重を負担し続けた。ただし, 亀裂発生後は柱梁骨組が層せん断力 を支配的に負担した。ここで, 柱脚側ブレース端部の局部座屈発生 は剛接合により, 骨組から端部に働く強制曲げが原因と考えられる。 厚肉鋼管ブレース試験体は, 図 11 に示寸ように, $\varphi=1 / 100 \mathrm{rad}$ で 骨組面内方向にブレースが全体座屈を生じ， $\varphi=1 / 33 \mathrm{rad}$ の 1 cycle に て柱脚側端部が引張破断した。同ブレースは径厚比が比較的小さく, 式(3)で評価される局部座屈発生歪 $a_{10}$ 下限值 ${ }^{15}$ は約 $2 \%$ 程度であり, 載荷履歴内で局部座屈を伴う早期破断は生じないと想定したが，ブ レース端部の溶接仕様に欠陥がみられ想定より早期に破断した。

$$
\varepsilon_{1 \mathrm{~b}}=0.0683 \varepsilon_{\mathrm{y}}{ }^{-0.39}\left(\frac{\mathrm{D}}{\mathrm{t}}\right)^{-1.39}
$$

平鋼ブレース試験体は, 図 12 に示寸ように, $\varphi=1 / 250 \mathrm{rad}$ でブレ ースが全体座屈を生じた。平鋼ブレースは圧縮耐力を期待できず履 歴性状はスリップ型となる。その後 $\varphi=1 / 50 \mathrm{rad}$ の 1cycle で, 写真 1(d), 付録 1 に示すように，平鋼ブレースは中央接合部で引張破断を生じ た。中央接合部は断面欠損に伴い保有耐力接合が満たされておら ず ${ }^{22)}$, 同試験体は体育館等に配置されるX 型ブレースの被災報告と 同じ破壊メカニズムを呈した ${ }^{16)}$, 17)。全試験体共通の梁は, 図 10(b) に示すように, $\varphi=1 / 50 \mathrm{rad}$ で梁端降伏し, $\varphi=1 / 33 \mathrm{rad}$ でフランジに局 部座屈発生し, 26 29cycle で写真 1(e)に示寸左側の局部座屈部に亀 裂を生じ, 梁端溶接部の破断とは異なる破壊メカニズムを呈した。

表 3 にブレース累積変形性能の比較を示す。累積等価軸歪および 無次元化累積歪エネルギー $\chi_{w}$ はブレースが亀裂を生じるまでの值で あり， $\chi_{\mathrm{w}}=\int \sigma \mathrm{d} \varepsilon / \sigma_{\mathrm{y}}$ である。厚肉鋼管ブレースおよび平鋼ブレースは 局部座屈に伴う早期破断を生じていないものの, 薄肉鋼管ブレース よりも塑性歪が接合部に集中し, 累積変形性能が劣る結果となった。 以上の結果は全体として累積変形性能に優れた断面を有するブレー スも接合部設計を適切に行わないと早期に破断する危険性を示寸。

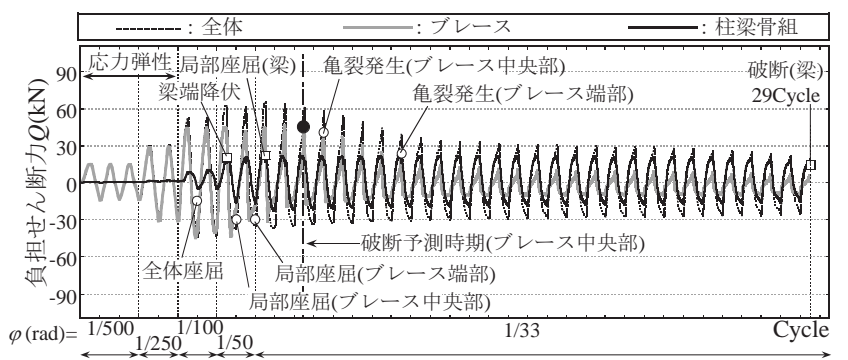

(a) 負担せん断力履歴

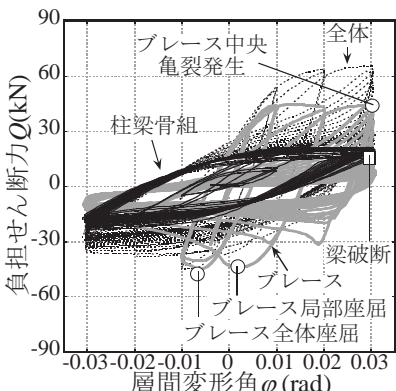

(b) $Q-\varphi$ 関係

図 10 薄肉鋼管ブレース試験体実験結果

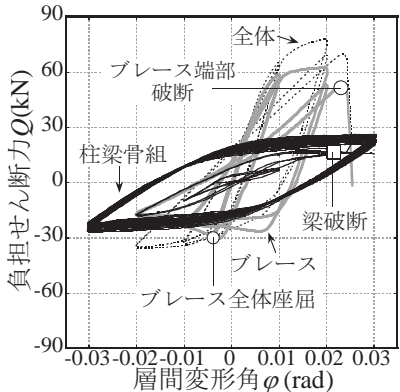

(a) Q - $\varphi$ 関係
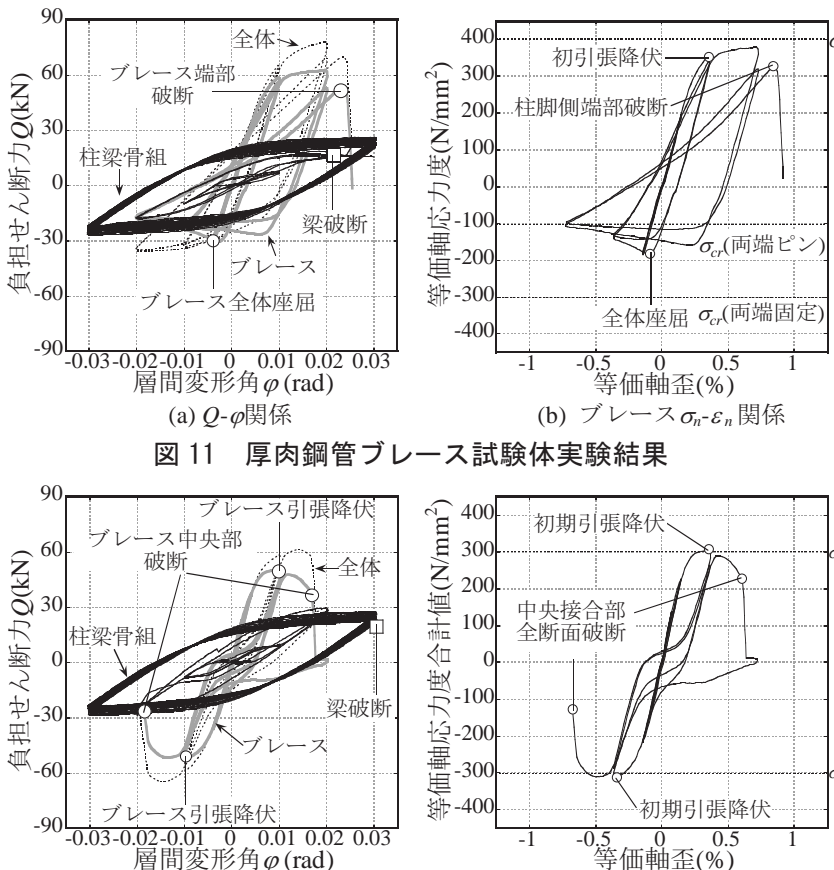

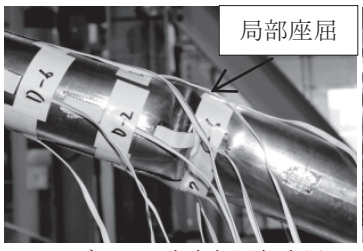
(a) ブレース中央部局部座屈
(薄肉鋼管ブレース試験体)

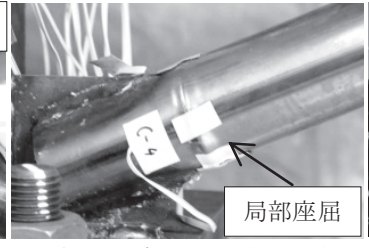

(b) 柱脚側ブレース端部局部座屋 (薄肉鋼管ブレース試験体)

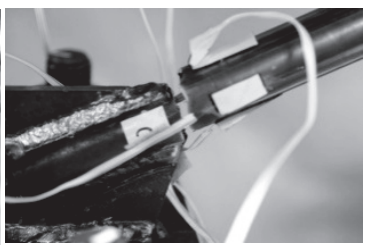

(c) 柱脚側端部引張破断 (厚肉鋼管ブレース試験体) 写真 1 試験体状況
図 11 厚肉鋼管ブレース試験体実験結果

(a) Q - $\varphi$ 関係

図 12 平鋼ブレース試験体実験結果

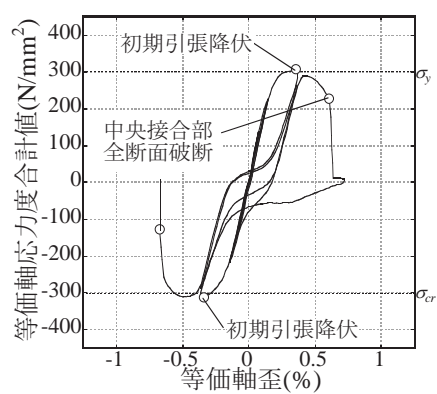

(b) ブレース $\sigma_{\mathrm{n}}-\varepsilon_{\mathrm{n}}$ 関係

表 3 ブレース部累積変形性能評価

(b) ブレース $\sigma_{\mathrm{n}}-\varepsilon_{\mathrm{n}}$ 関係

\begin{tabular}{|c|c|}
\hline $\begin{array}{c}\text { 累積 } \\
\text { 等価軸丕 } \\
\sum \varepsilon_{\mathrm{n}}(\%)\end{array}$ & $\begin{array}{c}\text { 無次元化累積 } \\
\text { 歪エネルギ } \\
\chi_{\mathrm{w}}(\%)\end{array}$ \\
\hline 24.91 & 7.00 \\
\hline 11.67 & 2.07 \\
\hline 7.10 & 1.47 \\
\hline
\end{tabular}

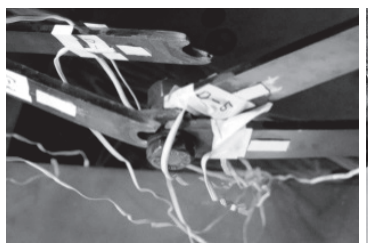

(d) 中央接合部破断 平鋼ブレース試験体)

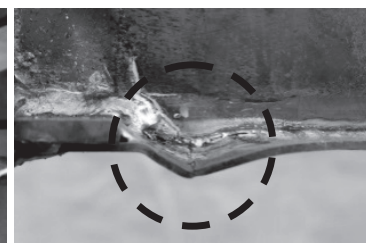

(e) 左側梁下フランジ局部座屈 部破断(全試験体共通) 


\section{2 振動台実験における実験系の固有振動特性}

次に薄肉鋼管ブレース試験体 $(D / t=42.3)$ を対象に振動台実験を行 い動的崩壊挙動および部材破断後の地震応答を分析する。弾性振動

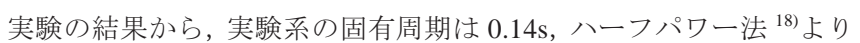
求めた減衰定数は $\mathrm{h}=4.6 \%$ である。実大換算した固有周期は $0.30 \mathrm{~s}$ で あり中低層建物の固有周期帯に対応寸る。図 13 に倒壊実験時の入力 地震動の応答スペクトルを示す。同図(b)(c)に示すように, $S_{v}, S_{d}$ ス ペクトルは入力目標值との対応が確認できた。

\section{3 倒壊実験におけるブレース付鋼構造骨組の動的崩壊挙動}

図 14 に得られた応答層間変形角の時刻歴を, 図 15 図 17 に荷重変形関係を, 写真 2 写真 4 に試験体状況を示寸。初めの倍率 $100 \%$ 入力では, 図 15(a), 図 16(a)に示寸ように, ブレースは全体座屈と 引張降伏を生じたが, 最大応答が $\varphi=1 / 123 \mathrm{rad}$ で静的入力時(図 10 , 図 11)の $\varphi=1 / 100 \mathrm{rad}$ より小さく, 耐力が低下せずに層せん断力を支 配的に負担し続けた。次の倍率 $150 \%$ の 1 回目入力では, ブレース 中央部のみ局部座屈と亀裂が生じ, 柱梁骨組の負担せん断力が上昇 して図 15(b), 図 17(a)に示すように梁端が曲げ降伏した。続く倍 率 150\%の 2 回目入力では, ブレースが全断面破断し, 図 14 に示す ように層間変形角 $\varphi$ が正方向に増大を始め, 梁端部は静的入力と同 じ局部座屈が確認された。最後の倍率 $150 \%$ の 3 回目入力では, さ らに層間変形角 $\varphi$ が増大し, 図 17(C)に示寸梁端部の亀裂が生じて写 真 2 に示寸状態に至った。残留值は $\varphi=$ 約 $1 / 6 \mathrm{rad}$ で, 試験体は倒壊と 判断した。ブレース部材の亀裂発生と全断面破断は発生時期に差が あり, 振動軸の移動や変位応答の増大は全断面破断時に顕著となる。

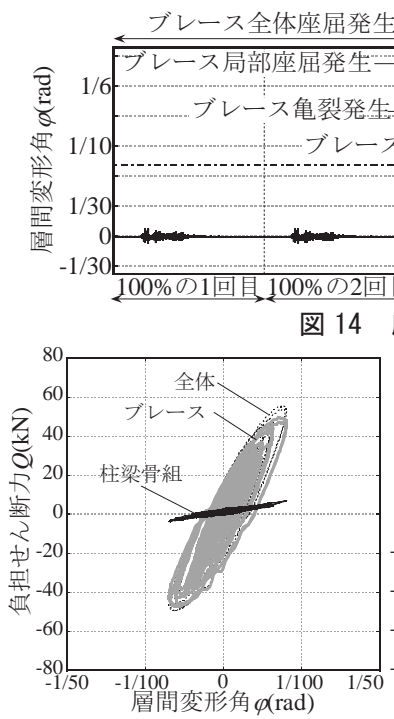

梁端降伏 梁局部座屈発生梁端部破断

(a) $100 \% 1$ 回目入力

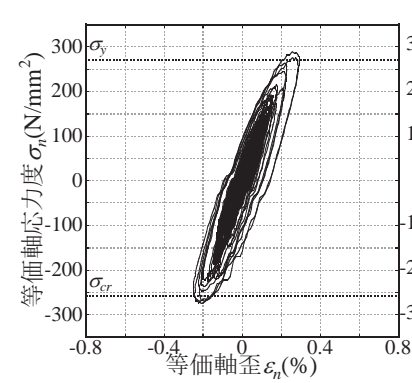

(a) $100 \% 1$ 回目入力

$0.8-0.8$

図 16 ブレース $\sigma_{n}-\varepsilon_{n}$ 関係(亀裂発生まで掲載)

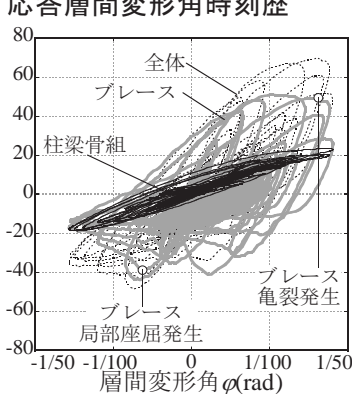

(b) $150 \% \quad 1$ 回目入力
図 15

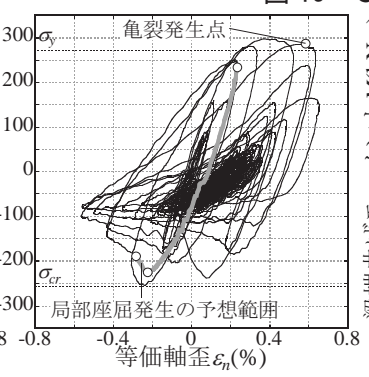

(b) $150 \% \quad 1$ 回目入力

\section{4 静的および動的入力による崩壊挙動の比較}

部材破断後の地震応答において, 層せん断力は図 15(c)に示すよう に, 静的入力で確認した柱梁骨組の最大耐力(25 30kN)を一時的に超 えた。これは写真 4 に示すように, ブレース全断面破断直後に破断 面同士が衝突したためである。本実験ではブレース破断後に正方向 に振動軸が移動しため, 以後の入力で衝突現象は再発しなかった。 静的な繰返しの崩壊挙動において, 梁は写真 1(e)に示すように, $\varphi=1 / 33 \mathrm{rad}$ で局部座屈部に亀裂を生じるが, 動的な倒壊挙動ではブ レース全断面破断後の振動軸の移動により変位応答が著しく増大し, 一方向に大きな曲げ変形 $(\varphi=+1 / 6 \mathrm{rad})$ を受けて, 写真 3 に示すように 梁端下フランジが破断する場合がある。

図 18 に亀裂発生までのブレース応力-歪関係を重ねて示す。各入 力は載荷履歴や最大応答が異なるものの, 動的入力における亀裂発 生までの履歴性状や最大耐力は, 静的入力時の歪振幅範囲内で概补 対応し動的効果は確認されなかった。また, 動的入力では柱脚側ブ レース端部に局部座屈を生じなかったが，これは静的入力では等価 軸歪振幅 $\Delta \varepsilon_{n}=1.44 \%$ で端部に局部座屈を生じたが, 動的入力では経 験した最大等価軸歪振幅 $\Delta \varepsilon_{n}$ が $1.0 \%$ 程度であったためと考えられる。
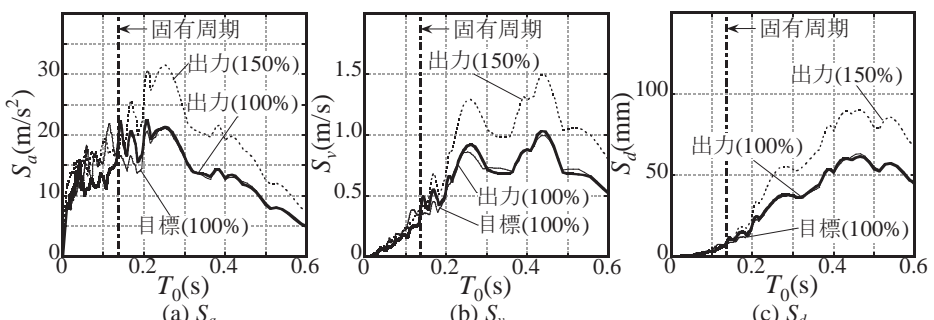

図 13 入力地震動の応答スペクトル $(h=4.6 \%)$

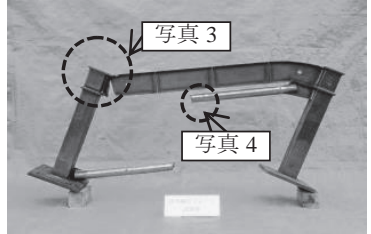

写真 2 倒壊状態(載荷後)

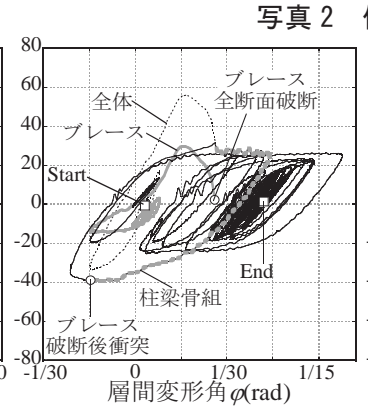

(c) $150 \% \quad 2$ 回目入力

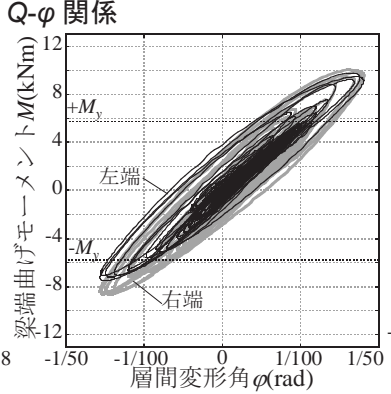

(a) $150 \% \quad 1$ 回目入力

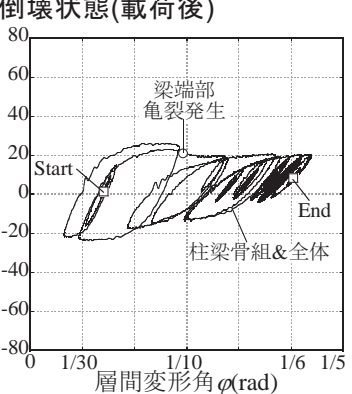

(d) $150 \% 3$ 回目入力

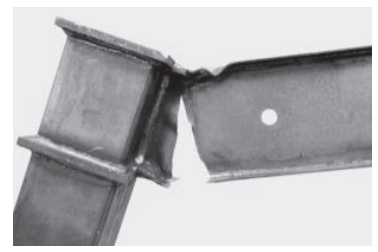

写真 3 梁端破断状況

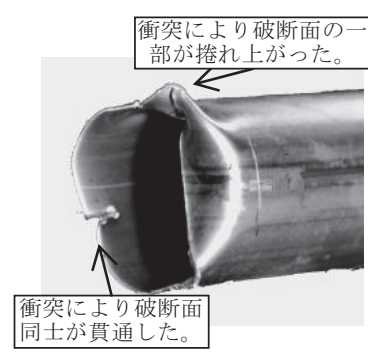

写真 4 ブレース破断面

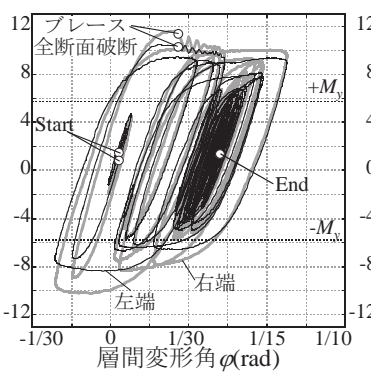

(b) $150 \% 2$ 回目入力

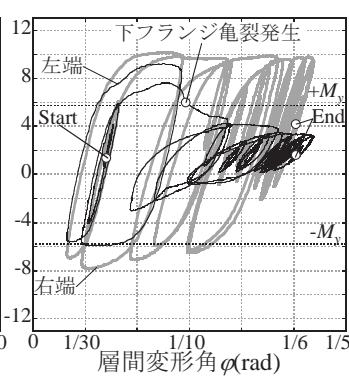

(c) $150 \% 3$ 回目入力

図 17 梁端 $M-\varphi$ 関係 (梁端降伏以降のみ掲載) 


\section{5 ブレース部材の破断時期評価手法の妥当性と動的崩壊挙動}

実験のブレース応力歪履歴を用いて既往の部材破断時期評価手 法 ${ }^{3)}$ の妥当性を検証し, 入力による累積変形性能の差異を分析する。

円形鋼管ブレースの部材破断時期評価手法では，ブレース中央の 局部座屈部に集中する塑性歪 $\boldsymbol{h}_{\mathrm{h}}$ の累積変形性能值に対し, 鋼素材の 疲労破断条件式 $\Sigma \Delta \varepsilon \mathrm{ch}_{\mathrm{p}}=3857{\overline{\Delta \mathrm{hn}^{-1.13}}}^{-1}$ 適合して部材破断(亀裂発生)を 評価する ${ }^{3)}$ 。図 19 に塑性歪集中部のモデルを示す。同評価法では, 部材の等価軸歪振幅 $\Delta \varepsilon_{n}$ に対寸る局部座屈部の局部歪振幅 $\Delta \varepsilon_{n}$ の比を, 歪振幅履歴により変動する歪振幅拡大係数 $\alpha_{c}$ として, 同図を仮定し て式(4)より算出する。また, 径厚比 $D / t>35$ の円形鋼管ブレースで 局部座屈後に母材中央部に集中寸る歪が縁部に移行する知見 ${ }^{19)} よ り$, 修正係数 $\beta_{\mathrm{c}}\left(\right.$ 式(5))を用いて $\alpha_{\mathrm{c}}$ を換算する。局部歪履歴の平均塑性歪 振幅 $\overline{\Delta \varepsilon h p}$ は, レインフロー法を用いて算出する。ここで, 振幅值を 用いた全体座屈や局部座屈が発生する時期の評価は, 時刻歴応答解 析への組み込みを意図した安全側の処置である。

$\alpha_{c}= \begin{cases}1 & \text { (全体座屈前 : } \Delta \varepsilon_{\mathrm{n}}<\varepsilon_{\mathrm{cr}} \text { ) } \\ \frac{\theta_{\mathrm{n}} \mathrm{D}}{\mathrm{L}_{\mathrm{k}}\left(1-\frac{\pi}{4}\right) \Delta \varepsilon_{\mathrm{n}}} & \text { (全体座屈後 : } \varepsilon_{\mathrm{ncr}} \leq \Delta \varepsilon_{\mathrm{n}}<\varepsilon_{\mathrm{b}} \text { ) } \\ \frac{3 \sqrt{6} \varphi_{\mathrm{n}} \beta_{\mathrm{c}}}{2 \pi \sqrt{\frac{D}{\mathrm{t}}} \Delta \varepsilon_{\mathrm{n}}}+\frac{\theta_{\mathrm{b}} \mathrm{D}}{\mathrm{L}_{\mathrm{k}}\left(1-\frac{\pi}{4}\right) \Delta \varepsilon_{\mathrm{n}}} & \text { (局部座屈後 : } \varepsilon_{\mathrm{lb}} \leq \Delta \varepsilon_{\mathrm{n}} \text { ) }\end{cases}$

$\beta_{c}= \begin{cases}1 & (D / t<35) \\ \frac{1}{15}\left(\frac{D}{t}\right)-\frac{4}{3} & (35 \leq D / t<50) \\ 2 & (50 \leq D / t)\end{cases}$

ここに，，中局部歪， $\varepsilon_{\mathrm{n} t \mathrm{~m}}$ は経験した最大引張等価軸歪， $\mathrm{L}_{\mathrm{k}}$ は有効座 屈長さ, $\sigma_{\mathrm{cr}}$ は部材の等価軸座屈応力度, $\mathrm{I}_{\mathrm{p}}$ は局部座屈半波長, $\varepsilon_{\mathrm{cr}}=\sigma_{\mathrm{cr}} / \mathrm{E}$, $\varepsilon_{\mathrm{b}}=0.0683 \varepsilon_{\mathrm{y}}^{-0.39}(\mathrm{D} / \mathrm{t})^{-1.39}, \quad \Delta \varepsilon_{\mathrm{n}}=\varepsilon_{\mathrm{ntm}}-\varepsilon_{\mathrm{n}}, \quad \Delta \varepsilon_{\mathrm{h}}=\varepsilon_{\mathrm{ntm}}-\varepsilon_{\mathrm{h}}, \quad \theta_{\mathrm{h}}=\cos ^{-1}\left(1-\Delta \varepsilon_{\mathrm{n}}\right)$, $\theta_{\mathrm{lb}}=\cos ^{-1}\left(1-\varepsilon_{\mathrm{b}}\right), \quad \Delta \theta_{\mathrm{h}}=\theta_{\mathrm{h}}-\theta_{\mathrm{b}}, \quad \varphi_{\mathrm{h}}=\cos ^{-1}\left[\left\{\cos \left(\Delta \theta_{\mathrm{h}}\right)-\mathrm{D} \sin \left(\Delta \theta_{\mathrm{h}}\right)\right\} / \|_{\mathrm{p}}\right.$ である。

図 20 に亀裂発生までの局部歪評価值の履歴を, 表 4 に亀裂発生時 期を示す。評価法は局部座屈発生を安全側に評価するため, 亀裂が 発生する時期は実験結果より早く判定される。一方, 局部座屈の発 生時期として実験結果を採用した場合(図表中の座屈時期補正)では, 静的入力に対して $\varphi=1 / 33 \mathrm{rad}-1$ cycle, 動的入力に対して約 $2.5 \mathrm{~s}$ 程度 の誤差で亀裂発生を予測できる。したがって, 著者らが提案する部 材破断時期評価手法は, 本検討の範囲内において骨組内のブレース に対し動的なランダム入力下でも適用可能と考えられる。

図 21 に局部歪評価值を用いた累積変形性能值と破断条件式の比 較を示す。静的入力では振幅が漸増することで, 平均塑性歪振幅 $\overline{\Delta \mathrm{chp}_{\mathrm{n}}}$ の増大が卓越して破断判定となるが，動的入力ではブレースが全体 座屈を経験し, 図 20(b)に示すような振幅の小さい振動を繰り返すた め, 累積塑性歪 $\Sigma \Delta \varepsilon_{\mathrm{hp}}$ が増大して破断判定となる。なお，例えば局部 座屈により著しく塑性化が進展する倍率 $150 \%$ の 1 回目入力のみを 評価した場合でも， $\overline{\Delta \varepsilon_{\mathrm{hp}}}$ は最大応答を受けて瞬間的に増大してから 減少に転じ, 最終的に $\overline{\Delta \varepsilon \mathrm{np}}=7 \%$ 程度で破断判定となる。以上の結果 は, 全体座屈を生じる程度の地震応答を経験したブレースは, 一度 の大地震に限らず, 余震等の小地震の繰返しを受けることで累積疲 労損傷により部材破断を生じる可能性を示唆している。
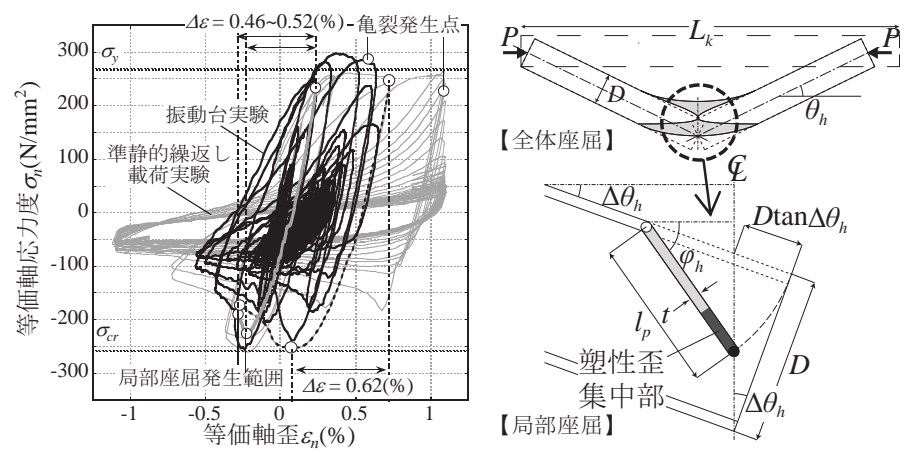

図 18 ブレース履歴の比較

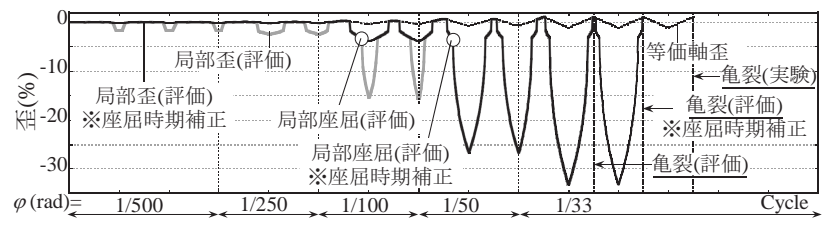

（a）準静的繰返し載荷実験(静的入力)

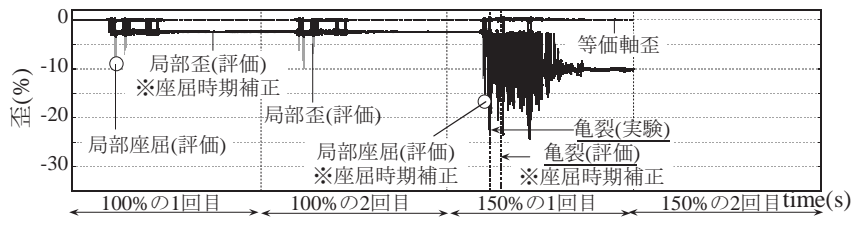

(b) 振動台実験(動的入力)

図 20 既往部材破断時期評価手法を用いた局部歪履歴評価

\section{表 4 亀裂発生時期の評価}

\begin{tabular}{|c|c|c|}
\hline $\begin{array}{c}\text { 亀裂発生 } \\
\text { 時期 }\end{array}$ & $\begin{array}{l}\text { 準静的繰返 } \\
\text { 乙載荷実験 }\end{array}$ & 振動台実験 \\
\hline 評価 & $\begin{array}{c}\varphi=1 / 33 \mathrm{rad} \\
2 \text { cycle }\end{array}$ & $\begin{array}{l}\text { 150\%-1回目 } \\
\text { 通算101.9s }\end{array}$ \\
\hline \begin{tabular}{c|} 
評価※ \\
座屈時期補正
\end{tabular} & $\begin{array}{c}\varphi=1 / 33 \mathrm{rad} \\
3 \text { cycle }\end{array}$ & $\begin{array}{l}150 \%-1 \text { 回目 } \\
\text { 通算101.7s }\end{array}$ \\
\hline 実験 & $\begin{array}{c}\varphi=1 / 33 \mathrm{rad} \\
4 \text { cycle }\end{array}$ & $\begin{array}{c}150 \%-1 \text { 回目 } \\
\text { 通算99.2s }\end{array}$ \\
\hline
\end{tabular}

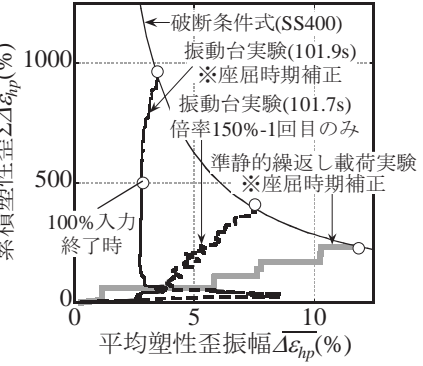

図 21 破断条件式との対応

\section{4. 準静的繰返し載荷実験の数值解析的検証}

4 章では準静的繰返し載荷実験について, 薄肉鋼管ブレース試験 体を対象に有限要素法 ${ }^{20)}$ を用いた数值解析を実行し, 変形が複雑化 するブレース中央局部座屈部の歪分布性状を分析し，既往論文で提 案されている歪振幅拡大係数 $\alpha_{\mathrm{c}}$ の対応を検証する。また，梁端の局 部座屈部について破壞モデルを仮定して累積変形性能評価を試みる。

\section{1 解析概要}

図 22 に解析モデルを示す。本解析では試験体，ピン治具，一部の 加力治具をモデル化する。柱梁骨組は 4 節点シェル要素(一部 3 節点 シェル要素)を用い, 局部座屈を生じた梁端部は $5 \mathrm{~mm} \times 5 \mathrm{~mm}$ 程度で細 かく分割し，その他は $10 \mathrm{~mm} \times 10 \mathrm{~mm}$ で分割する。ブレースは 4 節点 シェル要素を用い, 局部座屈を生じた端部および中央部は $5 \mathrm{~mm}$ x5mm 程度で細かく分割し，その他は相対的に粗く分割する。G.PL は 3 節点シェル要素を用いる。ピン治具は剛体梁要素を用いる。加 力治具は剛体シェル要素を用い，ペナルティ法による接触を定義し て梁ウェブ板の面外変形の夕拘束する。柱，梁，ブレースの材料特 性は引張試験結果を用い, ヤング率 $\mathrm{E}$ は $2.05 \times 10^{5} \mathrm{~N} / \mathrm{mm}^{2}$, ポアソン 比 を適用寸る。ブレースは $L_{B} / 1000$ の正弦波半波の初期不整を骨組の 面内または面外方向に与える。ピン治具と梁ボルト接合部における 
加力点では, 図 22 に示寸境界条件を与え, 入力履歴は準静的繰返し 載荷実験と同様とする。図 23 に荷重-変形関係を示す。解析モデル は実験結果の挙動を概ね再現している。

\section{2 ブレース局部座屈部の歪分布性状と歪振幅拡大係数の対応}

図 24 に抽出要素を示す。ブレースは中央局部座屈部から要素を抽 出し, 歪が集中する中央部と縁部を定義する。図 25 に各方向歪の対 応を示す。縁部は変形が複雑化するが, 式(6)で定義される三軸相当 歪 $\mathrm{e}_{\mathrm{eq}}{ }^{21)}$ の比較より, 軸方向歪が卓越すると判断し主歪とする。

$$
e_{e q}=\sqrt{(2 / 3)\left(e_{z}^{2}+e_{r}^{2}+e_{\theta}^{2}+2 e_{z r}^{2}\right)}
$$

ここに, $e_{z}$ は軸方向歪, $e_{r}$ は径方向歪, $e_{\theta}$ は周方向歪, $e_{2 r}$ は軸径方 向せん断歪である。

図 26 に局部座屈部の軸方向歪の周方向分布を示寸。同図(a)に示 すように, 実験と同様に骨組の面外方向に座屈たわみが生じる場合 は片側の縁部に塑性歪が集中する。これは剛接合されたブレースに 骨組面内方向の強制曲げが働き, ブレースの面外座屈と連成するた めである。同図(a)中の写真に示すように, 実験時も片側の縁部から 亀裂が生じる様子が確認された。同図(b)に示すように, 骨組の面内 方向にブレースが座屈たわみを生じる場合は既往研究 ${ }^{19)}$ と同じく両 側縁部に対称的に集中する。

図 27 の縁部歪履歴より算出した歪振幅拡大係数 $\alpha_{\mathrm{c}}$ の比較に示す。 同図(a)に示すように, ブレースが面外座屈する場合は 2 方向曲げ変 形の影響より, 解析值が評価值をやや上回るものの, 縁部の歪集中 を換算する修正係数 $\beta_{c}$ を考慮した評価值は解析值における増大の傾 向を捉え, 同図(b)に示寸ように, 面内座屈寸る場合では解析值と概 放対応し, 座屈方向が歪振幅拡大係数に与える影響は小さい。

\section{3 梁端局部座屈部の累積変形性能評価法}

局部座屈部で亀裂を生じ, 梁端溶接部の脆性的破断 ${ }^{221}$ とは異なる 破壞性状を呈した梁端部の累積変形性能評価を試みる。図28に仮定 する破壊モデルを示す。モデルでは, 柱は剛体回転し, 梁端は降伏 後に局部座屈を生じると仮定し, 局部塑性歪振幅 $\Delta \varepsilon$ h

$$
\begin{aligned}
& \Delta \mathrm{L}=I_{p}\left(1-\cos \Delta \varphi_{\mathrm{h}}\right)=(\mathrm{h} / 2) \sin \varphi \\
& \Delta \varphi_{\mathrm{h}}=\cos ^{-1}\left\{1-\left(\mathrm{h} / 2 \mathrm{I}_{\mathrm{p}}\right) \sin \varphi\right\} \\
& \mathrm{I}_{\mathrm{hl}}=2\left(\mathrm{I}_{\mathrm{p}} / 2\right)\left(1-\mathrm{Z} / \mathrm{Z}_{\mathrm{p}}\right)=\mathrm{I}_{\mathrm{p}} / 3 \\
& \Delta \varepsilon_{\mathrm{hp}}=\left(\Delta \varphi_{\mathrm{h}} \mathrm{t}_{\mathrm{f}}\right) / \mathrm{I}_{\mathrm{hl}}=\left(3 \Delta \varphi_{\mathrm{h}}\right) /\left\{1.635\left(\mathrm{~B} / 2 \mathrm{t}_{\mathrm{f}}\right)\right\}
\end{aligned}
$$

ここに，B と $\mathrm{t}_{\mathrm{f}}$ はフランジの幅と板厚， $\mathrm{h}$ は梁せい, $\mathrm{I}_{\mathrm{p}}=1.635(\mathrm{~B} / 2)$ は 局部座屈波長, I I l は塑性化領域長, Z と Z $\mathrm{p}$ は局部座屈部を矩形断面 とした断面係数と塑性断面係数で, $Z / Z_{p}=2 / 3$ である。

提案評価法の妥当性を検証する。抽出要素は図 24 に示寸梁左端下 フランジ局部座屈部であり, 歪履歴より值の大きい方向を主歪とす る。図 30 に累積変形性能評価を示寸。同図(a)に示すように, 評価 值の $\Delta \varepsilon_{\mathrm{hp}}$ は解析值の傾向を捉えており, 評価法と鋼素材の疲労破断 条件式を比較して亀裂発生時期を判定する。同図(b)に示すように, 亀裂発生評価時期までの解析における梁端 M- $\varphi$ 履歴面積を足し合わ せ， $M_{\mathrm{y}} \varphi_{\mathrm{y}}$ より無次元化した累積吸収エネルギー量は実験值に対 し20\%程度の誤差で亀裂発生までの累積変形性能を予測できている。

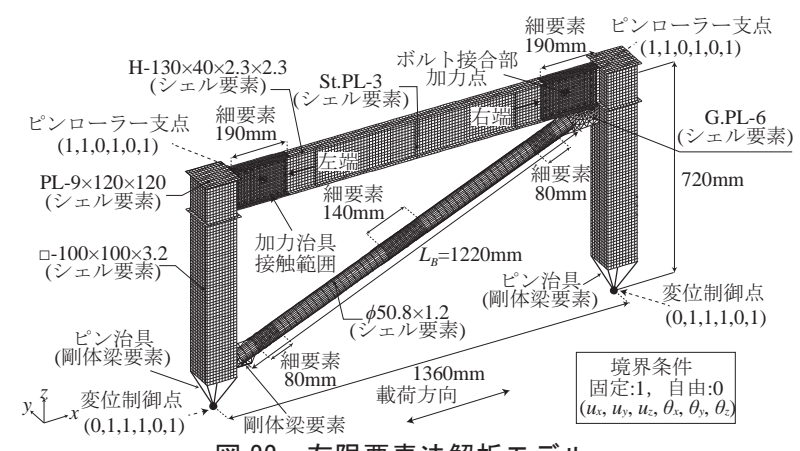

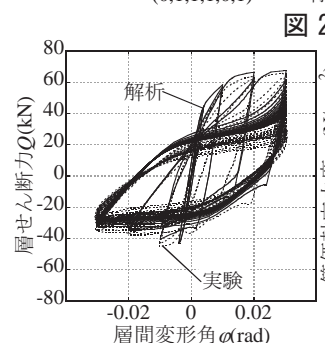
(a) 層 Q - $\varphi$ 関係
図 22 有限要素法解析モデル

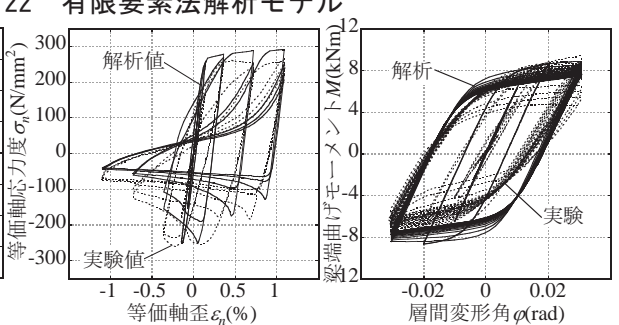

(b) ブレース $\sigma_{n}-\varepsilon_{n}$ 関係

(c) 梁左端 $M-\varphi$ 関係

\section{図 23 荷重-変形関係の対応性}

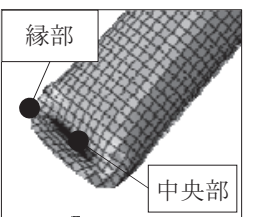

(a) ブレース中央

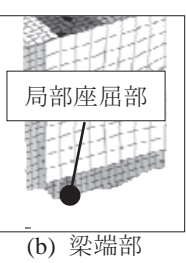

(b) 梁端部

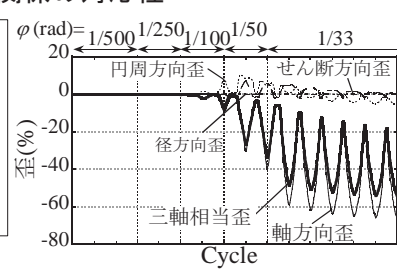

図 25 各方向歪の対応

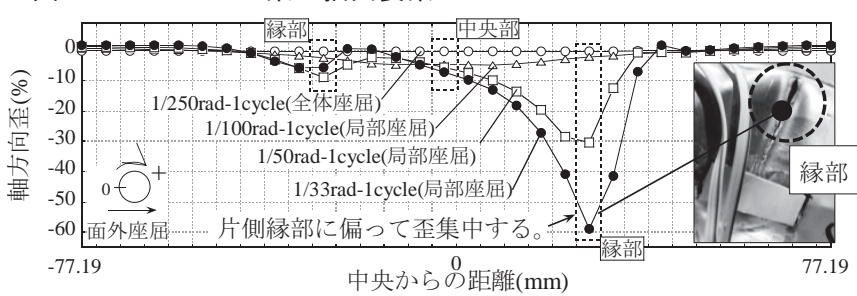

(a) 面外方向に座屈を生じる場合(実験と同様)

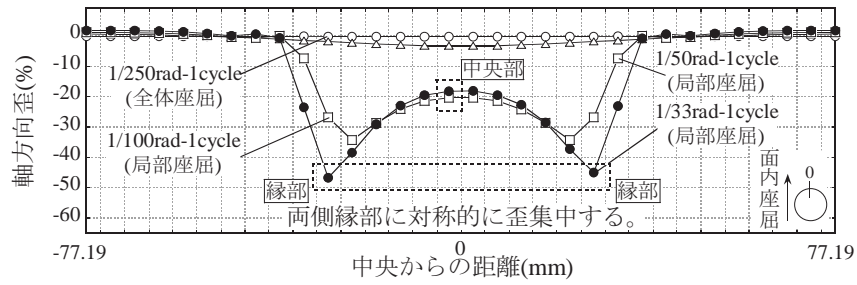

(b) 面内方向に座屈を生じる場合

図 26 ブレース中央局部座屈部における軸方向歪の周方向分布

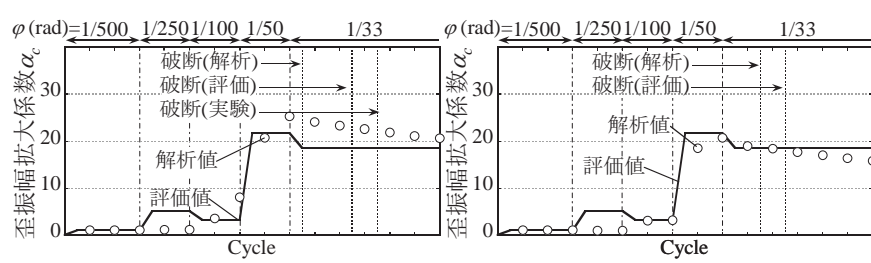

(a) 面外方向に座屈を生じる場合

(b) 面内方向に座屈を生じる場合

図 27 歪振幅拡大係数の対応性(縁部)

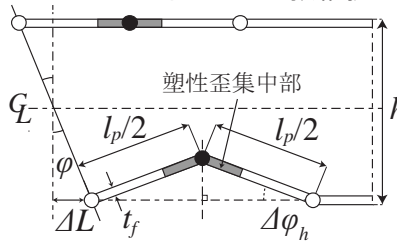

図 28 梁局部座屈モデル

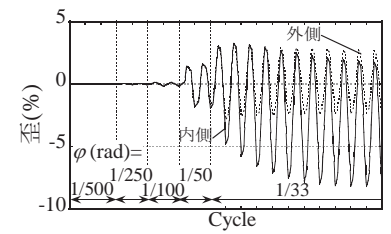

図 29 梁抽出要素の歪履歴 


\section{5. 振動台実験の数値解析的検証}

続く 5 章ではブレースの部材破断を考慮した時刻歴応答解析 ${ }^{3)}$ と 実験結果との対応を検証し，ブレース接合部の境界条件が亀裂発生 時期やブレース破断後の骨組の地震応答へ与える影響を分析する。

\section{1 解析モデルの設定と妥当性}

図 31 に解析モデルを示す。柱梁骨組は断面積と断面二次モーメン 卜が等価な梁要素とし, 梁の復元力特性は材料試験結果を参照した 弾塑性バイリニアモデルを設定する。また，下部治具を模擬する梁 要素で層剛性を，有効質量で弾性固有周期を調整する。ブレースは 座屈履歴則 ${ }^{23)}$ を組み込んだトラス要素を用いるモデル(トラス要素 モデル)と梁要素を用いるモデル(梁要素モデル)の 2 種類を検討対象 とする。トラス要素モデルは実験の初期座屈耐力を採用する。梁要 素モデルは，同図(b)に示すように，端部を剛接合として実験におけ る接合部の境界条件を考慮し, さらに中間節点を設けて実験時に確 認された個材振動を模擬する詳細なモデルであり, 全長の $10^{-3}$ 倍に 相当する初期不整を与え, 復元力特性は引張試験結果を参照した弾 塑性バイリニアモデルを設定する。一方，解析では幾何非線形性を 考慮し, 入力履歴は下部治具上の加速度記録值を用い, 構造減衰は $\mathrm{h}=4.6 \%$ の初期剛性比例型のレーリー減衰とする。ブレースは $\sigma_{\mathrm{n}}-\varepsilon_{n}$ 関係と, 3.4 節に示寸評価法と, 表 5 に示寸部材破断の設定を用い て破断を判定し，破断後は部材剛性を元の $10^{-4}$ 倍，負担荷重を零と 寸る ${ }^{3)}$ 。図 32 に静的増分解析結果を示寸。解析モデルは, 同図(a) (c) に示すように, 層剛性, 最大耐力, 梁端曲げ履歴性状の点で試験体 の力学的特性を再現し, 梁要素モデルは, 同図(d)に示すように, 耐 力の低下等を含めて座屈履歴側を設定したトラス要素モデルより静 的入力における実験結果を模擬している。

\section{2 解析結果}

図 33 にトラス要素モデルの解析結果を示す。同図(a)に示すよう に, 既往の評価手法に準ずる設定 1 では, ブレースは倍率 100\%の 1 回目入力で局部座屈が生じ, 最大応答後の弾塑性応答の差異から, 実験より早い倍率 $100 \%$ の 2 回目入力で破断と判定されるものの, 提案手法は安全側に評価できる。一方, 局部座屈発生時期として実 験值を採用した設定 2 では, 実験值から約 9s 遅れた倍率 150\%の 1 回目入力でブレースが破断し, 続く 2 回目, 3 回目入力では応答の 層間変形角 $\varphi$ の増大と振動軸の移動が生じ, 振動台実験の崩壊挙動 の傾向と対応する。ただし, 設定 2 では最大応答を生じた後の振動 が落ち着いた時点でブレースが破断と判定されたため, ブレース破 断直後に振動軸は移動していない。なお，同図(b)に示すように，実 験時の全断面破断時期を適用寸る設定 3 では，実験時と同様に破断 時にパルス的な応答加速度が生じ，破断時に部材剛性と負担荷重を 解放する手法により, 時刻歴応答解析で振動台実験の応答特性を模 擬できているものと考えられる。図 34 に梁要素モデルの解析結果を 示す。梁要素モデルの方がトラス要素モデルより実験結果に対する 最大応答の対応は良いが, 設定 2 の倍率 $150 \%$ 入力の 1 回目でトラ ス要素モデルの最大層間変形角は $1 / 63 \mathrm{rad}$ に対し, 梁要素モデルで は1/46rad となり両者の差異は30\%程度である。

表 6 にブレースの局部座屈発生と亀裂発生時期の比較を示す。局 部座屈発生時期を実験と合わせた設定 2 において, 実験時の境界条 件を考慮した梁要素モデルは, トラス要素モデルを用いた解析結果 より亀裂発生時期の評価精度が向上する。図 35 にブレース $\sigma_{n}-\varepsilon_{n}$ 関
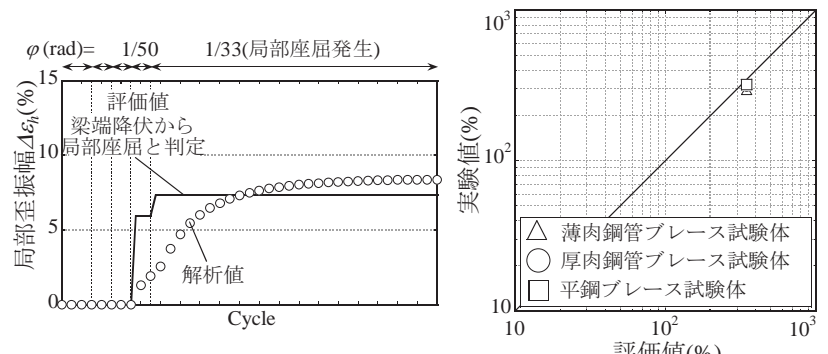

(a) 局所歪振幅の評価

(b) 無次元化累積吸収エネルギー量

図 30 梁局部座屈部の累積変形性能評価

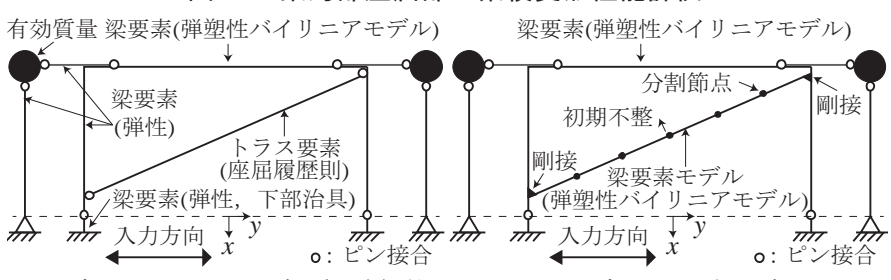

(a) ブレース:トラス要素+座屈履歴側

(b) ブレース:梁要素

図 31 骨組解析モデル

表 5 部材破断の設定

\begin{tabular}{c|c}
\hline 設定 & 部材破断の評価 \\
\hline 1 & ${\text { 既往評価法 }{ }^{3)} \text { に淮ずる }}$ \\
\hline 2 & $\begin{array}{c}\text { 既往評価法 }{ }^{3)}+\text { 局部座屈発生時期は } \\
\text { 実験と 同じく倍率150\%の1回目以降 }\end{array}$ \\
\hline 3 & 実験時の全断面破断時期を適用 \\
\hline
\end{tabular}

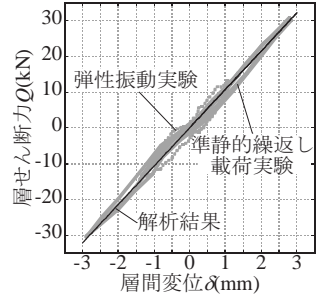

(a) 層剛性

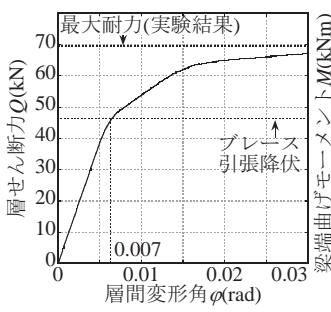

(b) 層 Q $-\varphi$ 関係

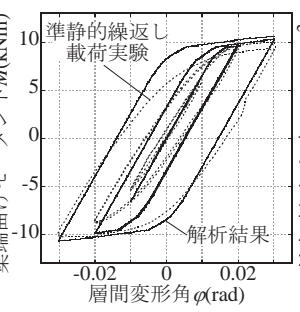

(c) 梁右端 $M-\varphi$ 関係

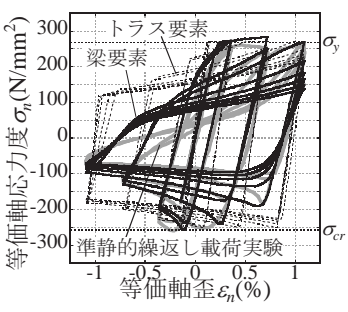

(d) ブレース $\sigma_{\mathrm{n}}-\varepsilon_{\mathrm{n}}$ 関係

\section{図 32 静的増分解析結果}

局部座屈発生(設定1) 破断(設定1)

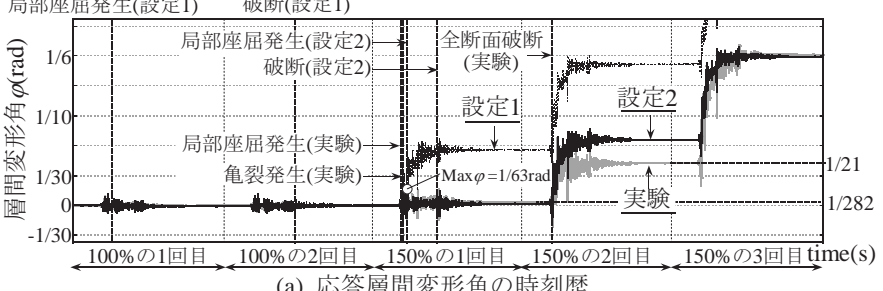

(a) 応答層間変形角の時刻歴

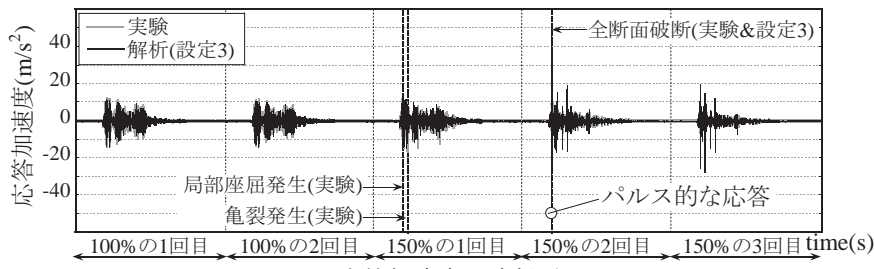

(b) 応答加速度の時刻歴

図 33 時刻歴応答解析結果(ブレース : トラス要素)

表 6 ブレースの局部座屈発生時期と亀裂発生時期の比較

\begin{tabular}{|c|c|c|c|c|c|}
\hline & トラス要素 & $\begin{array}{c}\text { トラス要素 } \\
\text { (座屈時期補正) }\end{array}$ & 梁要素 & $\begin{array}{c}\text { 梁要素 } \\
\text { (座屈時期補正) }\end{array}$ & 実験結果 \\
\hline $\begin{array}{c}\text { 局部座屈 } \\
\text { 発生 }\end{array}$ & $\begin{array}{c}100 \%-1 \text { 回目 } \\
\text { 通算11.3s } \\
\end{array}$ & $\begin{array}{c}\begin{array}{c}150 \%-1 \text { 回目 } \\
\text { 通算97.3s }\end{array} \\
\end{array}$ & $\begin{array}{c}100 \%-1 \text { 回目 } \\
\text { 通算 } 9.6 \mathrm{~s}\end{array}$ & $\begin{array}{c}\begin{array}{c}150 \%-1 \text { 回目 } \\
\text { 通算97.3s }\end{array} \\
\end{array}$ & $\begin{array}{r}150 \%-1 \text { 回目 } \\
\text { 通算97.8s } \\
\end{array}$ \\
\hline $\begin{array}{l}\text { 亀裂 } \\
\text { 発生 }\end{array}$ & $\begin{array}{c}100 \%-2 \text { 回目 } \\
\text { 通算65.7s }\end{array}$ & $\begin{array}{l}150 \%-1 \text { 回目 } \\
\text { 通算108.0s }\end{array}$ & $\begin{array}{c}100 \%-2 \text { 回目 } \\
\text { 通算 } 54.6 \mathrm{~s} \\
\end{array}$ & $\begin{array}{l}\text { 150\%-1回目 } \\
\text { 通算101.8s }\end{array}$ & $\begin{array}{r}150 \%-1 \text { 回目 } \\
\text { 通算 } 99.2 \mathrm{~s} \\
\end{array}$ \\
\hline
\end{tabular}




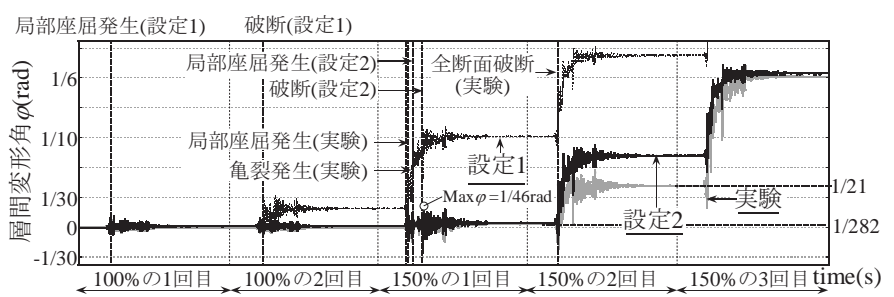

図 34 応答層間変形角の時刻歴(ブレース: 梁要素)

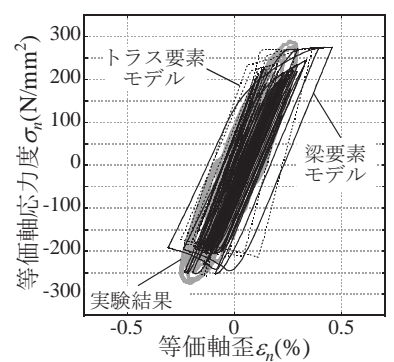

(a) 倍率 $100 \%$ 入力

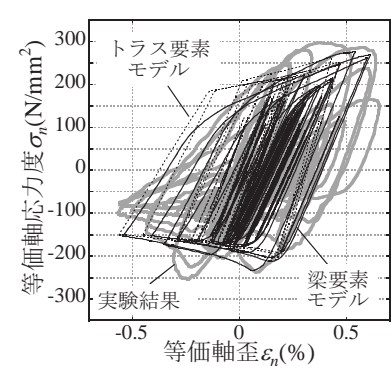

(b) 倍率 $150 \%$ 入力の 1 回目

\section{図 35 ブレース $\sigma_{n}-\varepsilon_{n}$ 関係(設定 2)}

係の比較を示す。梁要素モデルの方が最大 $\varepsilon_{n}$ の対応は良いが, モデ ルによる履歴性状の差異はあまり見られない。以上より, ブレース 挙動を模擬する要素の種類や, ブレース接合部の境界条件, 個材振 動がブレース破断後の骨組の地震応答に与える影響はほとんどない と判断できる。

\section{6. 結}

本研究は実大の $1 / 5$ サイズで 1 スパンのブレース付鋼構造骨組を 対象に各種載荷実験を実施し, 骨組内のブレース部材の動的崩壊挙 動や梁端部に亀裂が生じて骨組が倒壊に至るまでの地震応答性状な どを検証し，動的入力下における円形鋼管ブレース部材の破断時期 評価手法の精度や部材破断を考慮した時刻歴応答解析と実験結果の 対応を検証した。本研究の検討範囲内で得られた知見を以下に示す。 1)静的な入力において, 骨組に剛接合された径厚比 42.3 の薄肉鋼管 ブレースは中央部と端部に局部座屈を生じ, 骨組の面内方向の強 制曲げと面外方向の座屈たわみが連成する場合では, 中央部の片 側の縁部に歪集中寸る。また, 接合部施工状況によっては断面積 が等しく径厚比 11.8 の厚肉鋼管や平鋼等の, 局部座屈を生じにく いという点で断面性能が優位なブレースでも累積変形性能は薄肉 鋼管ブレースより低下寸る場合がある。

2)動的な入力において, 1 スパンのブレース付鋼構造骨組は, ブレ 一スの亀裂発生と全断面破断の発生時期に差があり, 変位応答の 増大や, 振動軸の移動は全断面破断後に顕著となる。また, ブレ 一ス部材が全断面破断した後の入力で層間変形角が $1 / 6 \mathrm{rad}$ まで増 大寸ると, 骨組は曲げ変形を受け梁端部の下フランジが破断する 3)円形鋼管ブレースの部材破断時期評価手法は, 局部座屈の発生が 早期に判定されるが, 実験の局部座屈発生時期を用いると, 静的 入力に対し $\varphi=1 / 33 \mathrm{rad}-1 \mathrm{cycle}$, 動的入力に対し $2.5 \mathrm{~s}$ の誤差で亀裂発 生を予測できた。これより, 同手法は骨組内のブレースに対し動 的入力下でも適用できることが確認できた。ただし, 施工不良や 非保有耐力接合のブレースは適用外である。

4)ブレースの部材破断を考慮した時刻歴応答解析は, ブレース破断 判定時に部材剛性と負担荷重を解放する手法で, ブレース付鋼構
造骨組の破断後における変位応答などの忘答特性を追跡できる 5)ブレース接合部の境界条件の設定は，ブレース破断の発生時期の 評価精度に影響を与えるが，ブレース破断後の骨組の地震応答性 状に大きな影響を与えない。

\section{謝辞}

本研究の一部は, 平成 25 年度科学研究費補助金若手研究 $(B)$ (課題 番号：24760448)および日本鉄鋼連盟における 2015 年度 鋼構造研 究・教育助成事業 鋼構造研究支援助成<建築分野> N 0.12 による研 究成果です。ここに記して謝意を表します。

参考文献

1) 内閣府, 中央防災会議 : 南海トラフ地震に係る地震防災対策の推進に関 する特別措置法関係，2014.3.28

2) 日本建築構造技術者協会 : JSCA 応答制御構造設計法・改訂シンポジウム 一巨大地震への対応一, 2013.5

3）松井良太，竹内 徹：部材破断を考慮したブレース付ラーメン骨組のエ ネルギー吸収性能, 日本建築学会構造系論文集, 第 76 巻, 第 665 号, pp.1337-1345, 2011.7

4) 長谷川隆, 福元敏之, 田上 淳, 澤本佳和, 久保田淳, 時野谷浩良, 鈴 井康正，寺田岳彦，石井大吾，成原弘之，安田 聡，金子洋文，宇佐美 徹，小鹿紀英，鈴木芳隆，西山功，向井昭義，岩田義裕：長周期地震 動に対する超高層鉄骨造建築物の耐震安全性に関寸る検討, 独立行政法 人建築研究所, 2014.7

5) 竹内 徹, 大山翔也，松井良太 : 繰返し曲げを受ける高強度鋼梁端部の 累積変形性能評価 - 制振部材を付加した高強度鋼架構の耐震性能 そ の 2 -, 日本建築学会構造系論文集，Vol.76，No.661，pp.695-702，2011.3

6) T.Takeuchi, R.Matsui: Cumulative Cyclic Deformation Capacity of Circular Tubular B races under L ocal Buckling, J ournal of Structural Engineering, ASCE, Vol.137, No.11, pp.1311-1318, 2011.11

7) 竹内徹, 近藤佑樹, 松井良太, 今村 晃：局部座屈を伴う組立材ブレー 又の座屈後履歴性状, 日本建築学会構造系論文集, Vol.77, N o.681, pp.1781-1790, 2012.11

8) 松井良太，廣山剛士，竹内 徹 : 梁端部破断を考慮したブレース付ラー メン骨組のエネルギー吸収性能, 日本鋼構造協会鋼構造論文集, 日本鋼 構造協会, Vol.20, No.79, pp.11-18, 2013.9

9) 松井良太, 潤井駿司，得能将紀，竹内 徹: ブレースおよび梁端部破断 を考慮した鋼構造骨組の耐震性能評価, 日本建築学会構造系論文集, Vol.80, No.717, pp.1745-1754, 2015.11

10）秋山宏，山田 哲，箕輪親宏，寺本隆幸，大竹章夫，矢部喜堂：慣性 加力装置を用いた構造要素の実大振動台実験方法, 日本建築学会構造系 論文集, N 0.505, pp.139-146, 1998.3

11) 長谷川隆：接合部パネルが塑性化する鉄骨構造骨組の地震応答性状に関 する振動実験，日本建築学会構造系論文集，No.528，pp.143-149，2000.2

12）山口路夫，山田哲，前田泰史，萩原夕き，竹内徹，成川匡文，中島正 愛, 和田 章: 実構造物の地震時挙動を再現する実大振動台実験手法の 提案 制振ダンパーを組み込んだ鋼構造骨組の耐震性その 1 - , 日本建築 学会構造系論文集, No.541, pp.179-186, 2001.3

13) D.G. Lignos, H.K rawinkler and A.S. W hittaker: Shaking table collapse tests of two scale models of a 4-story moment resisting steel frame, Proceedings of 14WCEE, China, 2008

14) Federal Emergency Management Agency : Recommended seismic design criteria for new steel moment-frame buildings, FEM A-350, 2000.6

15) 小川厚治，黒羽啓明，前田珠希：円形鋼管圧縮柱の座屈後挙動に関寸る 研究, 日本建築学会構造系論文集, N 0.475, pp.137-144, 1995.9

16) 日本建築学会: 東日本大震㷋合同調査報告 建築編 3 鉄骨造建築物 / シェル・空間構造, 2014.9

17) 小澤亮公，尾 澤聡，山下哲郎：山形鋼を用いた $X$ 型ブレースの耐震性 能に関する実験的研究-その 2. 繰返し加力実験結果とエネルギー吸収性 能の評価-, 日本建築学会大会学術講演梗概集(東北), C-1 分冊, 構造III, pp.803-804, 2009.8

18) 日本建築学会 : 建築物の減衰, 2000 
19) 竹内 徹, 堀内健太郎, 松井良太, 小河利行, 今村 晃 : 鋼管部材の座 屈および破断を考慮したトラス鉄塔の崩壊機構, 日本建築学会構造系論 文集，No.703，pp.1309-1319，2014.9

20) ABAQUS/Standard.ver.6.14-2

21) 桑村 仁, 山本恵市: 三軸応力状態における構造用鋼材の延性き裂発生 条件, 日本建築学会構造系論文集, N o.477, pp.129-135, 1995.11

22) 日本建築学会 : 鋼構造接合部設計指針, 2012

23) 柴田道生, 中村 武, 若林 實 : 鉄骨筋違の履歴特性の定式化, その 2 応答解析への適用, 日本建築学会論文報告集, No.320, pp.29-35, 1982.10

\section{付録 1}

付写真 1 に鋼管ブレースを配置した試験体のブレース端部を示す。 鋼管ブレースは, 薄肉と厚肉どちらも保有耐力接合を満たす溶接仕 様を設定したが，厚肉鋼管ブレースは G.PL を挿し込むために設け た製作時の切欠き部が溶接後も残存した。付図 1 に端部欠損を有す る場合の塑性歪分布を, また，付図 2 に端部欠損を再現した厚肉鋼 管ブレース試験体の FEM 解析結果を示す。同解析では, ブレース 端部を $1.5 \mathrm{~mm} \times 1.5 \mathrm{~mm}$ でメッシュ分割し, 切欠きが残存した部分に 相当する要素メッシュを削除してモデル化した。その他の設定は 4 章と同様である。付図 1 の平均塑性歪振幅は, 抽出要素の応力-歪履 歴とレインフロー法を用いて算出した。付図 1 および付図 2 に示す ように，切久き部が残存する場合では，接合端部近傍に塑性歪が集 中する。

付図 3 に平鋼ブレースの中央ボルト接合部図面の一部を示す。同 箇所は, 設計時に鋼構造接合部設計指針 ${ }^{22}$ にに示す保有耐力接合(最小 縁短距離)が満たされておらず，塑性歪が集中し，同指針に記される 局所的なちぎれ破断(写真 1(d))が生じた。

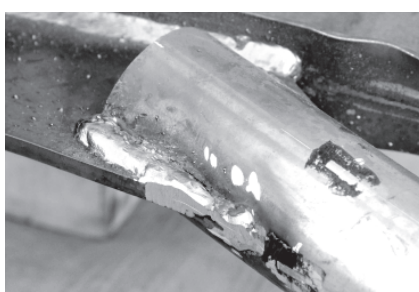

(a) 薄肉鋼管ブレース試験体

(切欠き部は溶接で埋められている。)

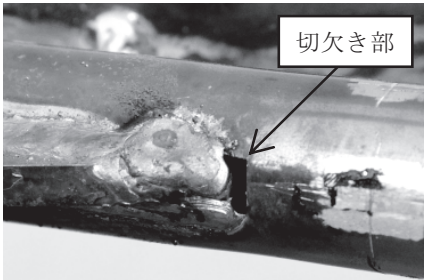

(b) 厚肉鋼管ブレース試験体 (切欠き部が残存)

付写真 1 鋼管ブレース端部 (柱頭側と柱脚側は同様)

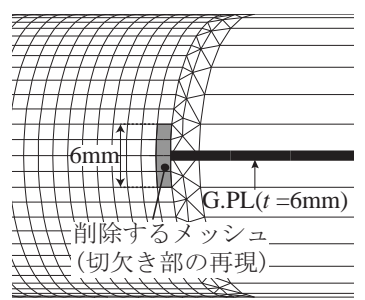

(a) FEM モデル部分詳細図 (柱脚側ブレース端部) 付図 1 端部欠損を有する場合の塑性歪分布 (厚肉鋼管ブレース試験体)

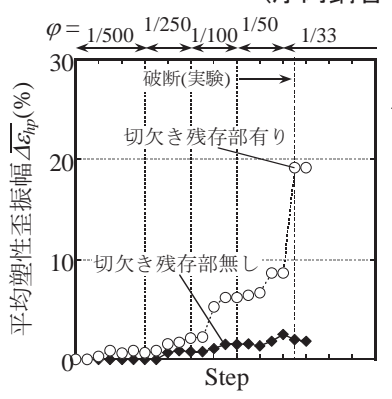

付図 2 塑性歪集中部における 平均塑性歪振幅の推移

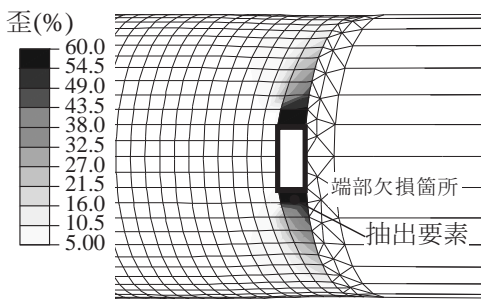

(b) 軸方向歪のコンター図 (実験時に破断を生じたステップ)

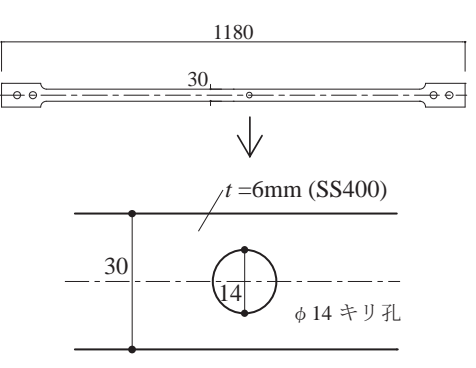

付図 3 平鋼ブレース交点の

ディテール 


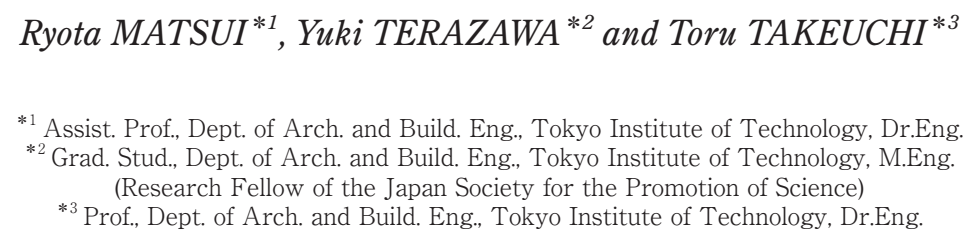

\section{Introduction}

The authors have proposed a method to assess the local fracture mechanism of moment frame connections and brace members under cyclic loading directly from global member results, termed the Direct Local Strain Evaluation M ethod. However, up to now, the accuracy of the proposed method has only been validated under static loading. This research validates the proposed method under dynamic loading with collapse tests.

\section{Test Setup}

A frame composed of a single bay moment frame and a concentric circular hollow section (CHS) brace was assembled for the dynamic collapse test, with LVDT strain gauges installed to monitor fracture of the brace and the beam connections. Initially quasistatic loading tests were carried out to confirm the fundamental mechanical properties of the braced frame specimens. The testing rig included an inertial mass system to simulate $\mathrm{P} \Delta$ effects large deformation.

\section{Quasistatic and Dyanamic Loading Tests on Braced Frames}

The diameter-thickness ratios of CHS brace of specimens ranged from 42.3 (slender) to 11.8 (compact). In the quasistatic tests, the slender specimens failed by local buckling at the midpoint and ends of the brace member, while local buckling was not observed for the compact specimens. However, when connection fracture governed, the cumulative deformation capacity of the brace was not necessarily determined by just the diameter-to-thickness ratio. In the dynamic loading test, the slender specimens, residual story drift angle was 1/282 rad at initiation of brace fracture, 1/21 rad following fracture of the brace and $1 / 6$ rad once the beam connection fractured.

\section{Numerical Investigation on Simulation of Quasistatic Loading Tests}

A series of FEM analyses were conducted in order to simulate of the quasistatic loading tests, where the member modelled with shell elements. The Direct Local Strain Evaluation M ethod is largely effective estimating the local strain of the brace member and at the beam connection.

\section{Validity of Direct Local Strain Evaluation Method under Dynamic Loading}

Numerical FEM models were also created to simulate of the dynamic loading test using stick models. The estimated initiation of local buckling was found to be more accurate using truss elements for the brace than by using bending elements. Generally, the post-brace-fracture displacements of a dual brace-moment frame system are much greater than the displacement contribution of local buckling. While local buckling can have a significant effect on the pre-brace fracture displacement, the precise instant that local buckling is initiated has a relatively small effect on the total displacement response of a frame with brace fracture. The proposed method is effectively predicted the braced frame response including the brace fracture under dynamic loading.

\section{Conclusions}

In summary, the following results were obtained:

1) Local buckling occurred at the midpoint and ends of the brace for slender CHS specimens, while local buckling of compact CHS specimens was not observed in the quasistatic loading tests.

2) In the dynamic loading test of the slender CHS specimens, the residual story drift angle was $1 / 282$ rad at initiation of brace fracture, $1 / 21$ rad following fracture of the brace and $1 / 6$ rad once the beam connection fractured.

3) The Direct Local Strain Evaluation M ethod is effective in estimating the local strain of the brace member and at the beam connection.

4) The proposed method effectively predicts the braced frame response including the brace fracture under dynamic loading. 